Bangl. J. Vet. Med. (2011). 9(1): 1 - 16

\title{
MORTALITY AND DISEASE STATUS IN HY-LINE AND ISA-BROWN STRAINS OF LAYER CHICKENS REARED IN CAGE SYSTEM IN BANGLADESH
}

\author{
M. Z. Uddin ${ }^{1}$, M. A. Samad ${ }^{2}$ and S. M. L. $\operatorname{Kabir}^{3}$ \\ Department of Medicine ${ }^{1,2}$, Department of Microbiology and Hygiene ${ }^{3}$, Faculty of Veterinary Science, \\ Bangladesh Agricultural University, Mymensingh-2202, Bangladesh
}

\begin{abstract}
Mortality and disease status in Hy-Line $(n=3450)$ and ISA-Brown $(n=250)$ strains of layer chickens were carried out in three commercial layer farms in the district of Mymensingh from day-old to 65 weeks age of birds from September 2003 to December 2004. The management including housing, hygienic measures, vaccination practices, diseases occurred and mortality were observed and recorded daily. Diseases and disorders were diagnosed based on the disease history, clinical signs, characteristics necropsy lesions, morbidity and mortality rates, and laboratory investigations including bacteriological and parasitological examinations. The morbidity and mortality of chickens caused by different diseases and disorders were statistically analyzed on the basis of farms, strains of birds, age and seasons. An overall $32.38 \%(\mathrm{n}=1198)$ morbidity and $21.30 \%(\mathrm{n}=788)$ mortality was recorded among 3700 chickens. Etiological analysis showed that the highest mortality caused by bacterial diseases $(7.08 \%)$, followed by viral diseases $(5.81 \%)$, fungal diseases $(2.18 \%)$, mycoplasmosis $(1.89 \%)$, parasitic diseases $(1.83 \%)$ and nutritional and other disorders $(2.48 \%)$. Specific diseases and disorders caused mortality in chickens included Salmonellosis $(3.14 \%)$, Colibacillosis $(2.51 \%)$, Fowl cholera $(0.46 \%)$, Infectious coryza $(0.41 \%)$, Necrotic enteritis $(0.59 \%)$, Infectious bursal disease (2.19\%), Newcastle disease (1.76\%), Avian leukosis $(0.73 \%)$, Fowl pox ( $0.51 \%)$, Marek's disease (0.62\%), Aspergillosis (1.54\%), Aflatoxicosis (0.65\%), Mycoplasmosis ( $1.89 \%)$, Ascaridiasis (0.22\%), Tapeworm infection $(0.16 \%)$, Coccidiosis $(1.32 \%)$, Ectoparasitosis $(0.14 \%)$, Nutritional deficiency $(0.68 \%)$, Ascites, Hydropericardium hepatitis syndrome $(0.49 \%)$, Cannibalism $(0.27 \%)$, Egg peritonitis $(0.22 \%)$, Egg bound disorder $(0.43 \%)$ and Heat stroke and cold $(0.41 \%)$. Diseases caused highest mortality during laying period $(8.43 \%)$, followed by growing $(6.32 \%)$, pullet stage $(4.65 \%)$ and brooding $(3.78 \%)$ ages. Both the morbidity and mortality rates in ISA-Brown strain $(62.60 \%$ and $37.20 \%)$ were found significantly $(\mathrm{p}<0.01)$ higher in comparison to Hy-Line $(30.17 \%$ and $20.14 \%)$ strain of chickens. Seasonal influences on mortality in layer type chickens showed significantly $(\mathrm{p}<0.01)$ highest mortality during summer $(8.57 \%)$, followed by winter $(6.51 \%)$ and rainy $(6.22 \%)$ months. It may be concluded that the infectious diseases even with vaccination associated with high morbidity and mortality in commercial egg type chickens in Bangladesh.
\end{abstract}

Key words: Morbidity, mortality, hy-line, ISA-Brown, layer chickens, necropsy, Bacteriological methods

\section{INTRODUCTION}

Poultry farming is emerging as a strong agro-based industry from the backyard poultry rearing system to commercial intensive rearing systems during the last two decades in Bangladesh. This rapid growth of poultry industry to supplement their income with the fast development of poultry industry, the occurrence of diseases has increased many folds which remain the major problem affecting its economy as a results disease play a vital role to better understand the status and pattern of diseases. The prevalence of chicken diseases diagnosed on dead birds have been reported from Bangladesh (Giasuddin et al., 2002; Sil et al., 2002; Islam et al., 2003; Saleque et al., 2003; Shil et al., 2003). The pattern of diseases with their etio-pathological findings of dead chickens based on diagnostic results of the Poultry Disease Diagnostic Center have been reported from Bangladesh as a single and concurrent infections (Rahman and Samad, 2003), systemic and miscellaneous diseases (Rahman and Samad, 2004), viral etiology (Rahman and Samad, 2005) and bacterio-pathological studies (Rahman et al., 2004). Mortality plays a major role in determining profit from egg type layers and is a function of dead and culled birds over the growth and production period. A negative association of mortality with net profit in chicken production has been reported by Zaheer-ud-Din et al. (2001), Asghar et al. (2000) and Farooq et al. (2002). Kitsopanidis and Manos (1991) also reported a reduction in net profit when mortality was more than 2 to $5 \%$, whereas North and Bell (1990) reported poor economic performance of egg type layers at mortality level of more than $10 \%$. Mortality in egg type chicken at any stage of life will affect performance of egg type layers, however,

*Corresponding e-mail address: masamad88bau@yahoo.com

Copyright (C) 2011 Bangladesh Society for Veterinary Medicine

All right reserved 1729-7893/0217/2011 


\section{Z. Uddin and others}

higher mortality during the laying period will badly affect productivity. This paper describes the current status of diseases and disorders with their causes associated with morbidity and mortality in Hy-Line and ISA-Brown strains of layer chickens at various stages of life reared in cage system in Bangladesh.

\section{MATERIALS AND METHODS}

This study was conducted on 3700 layer type chickens from day-old to 65 weeks of age at the three different commercial layer farms in the district of Mymensingh during the period from September 2003 to December 2004. These include Al-Arafa Poultry Complex, Suitiakhali; Master Poultry Farm, Sutiakhali and Noor Ali's Farm, Bhabkhali, and the layer birds of all the three farms reared in cage system. The main aims to investigate the morbidity and mortality associated with diseases and disorders with their causes in layer chickens reared in cage system

The management systems of the selected three layer farms were closely observed by regular visiting them intensively and by taking regular information from the owners of the farms. Data from the randomly selected three layer farms regarding shed capacity and cage size, flock size, sources of chicks, strains of chickens, cage management and hygiene, feed additives, vitamin-mineral supplements, treatment and egg production traits.

The signs of the disease if showed by the chickens of all the three farms were recorded properly. The morbidity, mortality, age of affection of various diseases and disorders were also recorded. The moribund and dead chickens were collected as soon as possible for necropsy. Diseases and disorders were diagnosed based on the history provided by the owners, clinical signs, characteristic post-mortem gross lesions, morbidity and mortality rates and laboratory investigations including bacteriological and parasitological examinations as described by Samad (2005).

The clinical signs exhibited by the individual bird during illness were recorded in detail by visiting and from the farm workers and the sick birds were also purchased from the selected farms with low price and maintained isolated in the Departmental experimental poultry shed to study the causative agents, clinical signs and postmortem lesions, and microbiological examinations of the samples. Fecal samples were examined directly under the microscope for detection of parasitic infection.

\section{Bacteriological examination}

Samples were collected by the sterilized cotton swabs from heart, liver, infected ova, infundibulum, peritoneal fluid, intestine and respiratory tract of the layer chickens (moribund and/or dead) suspected for salmonellosis and colibacillosis at necropsy and were kept into the test tube containing nutrient broth. These test tubes were then transported via thermo-flask containing ice to the bacteriological laboratory.

The swab containing test tubes with nutrient broth were incubated for growth of the causative organisms at $37^{\circ} \mathrm{C}$ for overnight. For primary cultures the broth samples were inoculated separately in nutrient agar (NA) and incubated at $37{ }^{\circ} \mathrm{C}$ for overnight. The colonies on the primary cultures were repeatedly sub-cultured in enriched and selective media by streak plate method until the pure culture with homogenous colonies was obtained. Blood agar (BA), Eosin-Methylene blue (EMB) agar, MacConkey agar (MA) and Salmonella-Shigella (SS) agar (HiMedia Laboratories Ltd., Mumbai, India) were used in the repetitive sub-cultures for isolation and identification of the causative agents as described by Cheesbrough (1985).

The isolated colonies of bacteria were stained with Gram's stain to study the morphological and staining characteristics of bacteria as described by Parker and Collier (1990). For the cultural characteristics, discrete colonies on the agar surface were observed. Their shape, size, consistency and color were observed carefully.

\section{Biochemical tests}

Carbohydrate fermentation tests using five basic sugars namely dextrose, sucrose, maltose, lactose and mannitol were performed for further diagnostic confirmation of the isolated bacteria in pure culture as per method described by Cheesbrough (1985). After incubation for 24 hours at $37{ }^{\circ} \mathrm{C}$ of the test tubes containing different sugars and test organisms, the fermentation was indicated by the change of phenol red to yellow color with the production of acid and/ or gas. 
The management systems and the vaccination schedule performed in the three different farms are presented in Table 1 and 2, respectively.

Table 1. Management practices of the randomly selected three layer chicken farms in Mymensingh district

\begin{tabular}{|lllll|}
\hline S/NParameters & Farm No. 1 & Farm No. 2 & Farm No. 3 \\
\hline (1) & Name of layer farm & Al-Arafa Poultry Complex & Master Poultry Farm & Noor Ali's Farm \\
(2) & Source of chicks & Kazi Farms Ltd. & Kazi farm Ltd. & Paragoan Poultry Farm Ltd. \\
(3) & Total No. of chickens & 3150 & 300 & 250 \\
(4) & Strains of chickens & Hy-Line & Hy-Line & ISA-Brown \\
(5) & Housing and Feeding & Intensive, hand made feed & Intensive, market feed & Intensive, market feed \\
(6) & Antiseptic foot bath & Used & Used & Used \\
\hline
\end{tabular}

Table 2. Vaccination schedule used in the three different layer farms in Mymensingh district

\begin{tabular}{|c|c|c|c|c|c|c|c|c|}
\hline \multirow[t]{2}{*}{$\mathrm{S} / \mathrm{N}$} & \multirow[t]{2}{*}{ Vaccines } & \multirow[t]{2}{*}{ Disease } & \multicolumn{2}{|c|}{ Farm No. 1} & \multicolumn{2}{|c|}{ Farm No. 2} & \multicolumn{2}{|c|}{ Farm No. 3} \\
\hline & & & $\begin{array}{l}\text { Age } \\
\text { (days) }\end{array}$ & $\begin{array}{l}\text { Dose and } \\
\text { route }\end{array}$ & $\begin{array}{l}\text { Age } \\
\text { (days) }\end{array}$ & $\begin{array}{l}\text { Dose and } \\
\text { route }\end{array}$ & $\begin{array}{l}\text { Age } \\
\text { (days) }\end{array}$ & $\begin{array}{l}\text { Dose and } \\
\text { route }\end{array}$ \\
\hline (1) & $\begin{array}{l}\text { IB + ND } \\
\text { (Intervet) }\end{array}$ & $\begin{array}{l}\text { IB and } \\
\text { ND }\end{array}$ & 5 & $\begin{array}{l}1 \text { drop in } \\
\text { one eye }\end{array}$ & - & - & 3 & $\begin{array}{l}1 \text { drop in } \\
\text { one eye }\end{array}$ \\
\hline (2) & $\begin{array}{l}\text { Gumboro D78 } \\
\text { (Intervet) }\end{array}$ & IBD & $\begin{array}{l}16 \text { an } \\
24\end{array}$ & $\begin{array}{l}1 \text { drop in } \\
\text { one eye }\end{array}$ & 25 & $\begin{array}{l}1 \text { drop in } \\
\text { one eye }\end{array}$ & $\begin{array}{l}14 \text { and } \\
22\end{array}$ & $\begin{array}{l}1 \text { drop in } \\
\text { one eye }\end{array}$ \\
\hline (3) & $\begin{array}{l}\text { Mv5 Clone-30 } \\
\text { (Intervet) }\end{array}$ & ND & 35 & $\begin{array}{l}1 \text { drop in } \\
\text { one eye }\end{array}$ & $\begin{array}{l}14 \text { and } \\
40\end{array}$ & $\begin{array}{l}1 \text { drop in } \\
\text { one eye }\end{array}$ & 30 & $\begin{array}{l}1 \text { drop in } \\
\text { one eye }\end{array}$ \\
\hline (4) & $\begin{array}{l}\text { Ovodipth erin } \\
\text { (Intervet) }\end{array}$ & Fowl pox & 45 & $\begin{array}{l}\text { Wing-web } \\
\text { pricking }\end{array}$ & b 49 & $\begin{array}{l}\text { Wing-web } \\
\text { pricking }\end{array}$ & - & - \\
\hline (5) & $\begin{array}{l}\text { Novivac coryza } \\
\text { (Intervet) }\end{array}$ & $\begin{array}{l}\text { Infectious } \\
\text { coryza }\end{array}$ & - & - & - & - & 42 & $\begin{array}{l}\text { SC } \\
(0.5 \mathrm{ml})\end{array}$ \\
\hline (6) & $\begin{array}{l}\text { Fowl cholera } \\
\text { (LRI) }\end{array}$ & $\begin{array}{l}\text { Fowl } \\
\text { cholera }\end{array}$ & - & - & 60 & $\begin{array}{l}\mathrm{SC} \\
(0.5 \mathrm{ml})\end{array}$ & - & - \\
\hline
\end{tabular}

IB = Infectious bronchitis, IBD = Infectious bursal disease, ND = Newcastle disease, $\mathrm{SC}=$ Sub-cutaneously

\section{Statistical analysis}

Results were analyzed statistically by using Chi-square $\left(\chi^{2}\right)$ test for significance in the mortality pattern of various diseases in layer birds in respect to age and seasons (Steel and Torrie, 1981).

\section{RESULTS AND DISCUSSION}

Characteristic clinical sign, necropsy and laboratory methods have been used to investigate the morbidity and mortality caused by diseases and disorders in 3700 layer egg type chickens of three different commercial poultry farms in the district of Mymensingh during the period from September 2003 to December 2004. Analysis of the results reveled that $1198(32.38 \%)$ layer birds were affected with different diseases, of which $788(21.30 \%)$ chickens died (Table 3). Of the $788(21.30 \%)$ dead chickens, $262(7.08 \%)$ died due to bacterial diseases, 215 $(5.81 \%)$ due to viral diseases, $81(2.19 \%)$ due to fungal diseases, $70(1.89 \%)$ due to mycoplasmosis, $68(1.84 \%)$ due to parasitic diseases and $92(2.49 \%)$ due to nutritional disorders and other causes (Table 3 and 4 ). 


\section{Z. Uddin and others}

Table 3. Susceptibility between Hy-Line and ISA-Brown strains of chickens to different diseases and disorders

\begin{tabular}{|c|c|c|c|c|c|c|c|c|c|c|c|}
\hline \multirow[t]{2}{*}{$\mathrm{S} / \mathrm{N}$} & \multirow[t]{2}{*}{$\begin{array}{l}\text { Diseases and } \\
\text { disorders }\end{array}$} & \multicolumn{2}{|c|}{$\begin{array}{l}\text { Farm-1 } \\
\text { Hy-Line } \\
(\mathrm{n}=3150)\end{array}$} & \multicolumn{2}{|c|}{$\begin{array}{l}\text { Farm-2 } \\
\text { Hy-Line } \\
(\mathrm{n}=300)\end{array}$} & \multicolumn{2}{|c|}{$\begin{array}{l}\text { Total } \\
\text { Hy-Line } \\
(\mathrm{n}=3450)\end{array}$} & \multicolumn{2}{|c|}{$\begin{array}{l}\text { Farm-3 } \\
\text { ISA-Brown } \\
(\mathrm{n}=250)\end{array}$} & \multicolumn{2}{|c|}{$\begin{array}{l}\text { Overall } \\
\text { Both strains } \\
(\mathrm{n}=3700)\end{array}$} \\
\hline & & $\begin{array}{l}\text { No. } \\
\text { sick } \\
(\%)\end{array}$ & $\begin{array}{l}\text { No. } \\
\text { died } \\
(\%)\end{array}$ & $\begin{array}{l}\text { No. } \\
\text { sick } \\
(\%)\end{array}$ & $\begin{array}{l}\text { No. } \\
\text { died } \\
(\%)\end{array}$ & $\begin{array}{l}\text { No. } \\
\text { sick } \\
(\%)\end{array}$ & $\begin{array}{l}\text { No. } \\
\text { died } \\
(\%)\end{array}$ & $\begin{array}{l}\text { No. } \\
\text { sick } \\
(\%)\end{array}$ & $\begin{array}{l}\text { No. } \\
\text { died } \\
(\%)\end{array}$ & $\begin{array}{l}\text { No. } \\
\text { sick } \\
(\%)\end{array}$ & $\begin{array}{r}\text { No. } \\
\text { died } \\
(\%)\end{array}$ \\
\hline \multicolumn{2}{|c|}{ A. Bacterial diseases } & $\begin{array}{l}\mathbf{2 8 1} \\
(8.92)\end{array}$ & $\begin{array}{l}\mathbf{2 0 5} \\
(6.51)\end{array}$ & $\begin{array}{c}\mathbf{5 1} \\
(17.00)\end{array}$ & $\begin{array}{c}32 \\
(10.67)\end{array}$ & $\begin{array}{c}\mathbf{3 3 2} \\
(09.62)\end{array}$ & $\begin{array}{c}\mathbf{2 3 7} \\
(06.87)\end{array}$ & $\begin{array}{c}\mathbf{4 4} \\
(17.60)\end{array}$ & $\begin{array}{c}\mathbf{2 5} \\
(10.00)\end{array}$ & $\begin{array}{c}\mathbf{3 7 6} \\
(10.16)\end{array}$ & $\begin{array}{r}\mathbf{2 6 2} \\
(7.08)\end{array}$ \\
\hline \multicolumn{2}{|c|}{ 1. Salmonellosis } & $\begin{array}{l}126 \\
(4.00)\end{array}$ & $\begin{array}{l}097 \\
(3.08)\end{array}$ & $\begin{array}{c}18 \\
(6.00)\end{array}$ & $\begin{array}{c}11 \\
(3.67)\end{array}$ & $\begin{array}{r}144 \\
(4.17)\end{array}$ & $\begin{array}{c}108 \\
(3.13)\end{array}$ & 14 & 08 & $\begin{array}{r}158 \\
(4.27)\end{array}$ & $\begin{array}{c}116 \\
(3.14)\end{array}$ \\
\hline \multicolumn{2}{|c|}{ 2. Colibacillosis } & $\begin{array}{l}095 \\
(3.02)\end{array}$ & $\begin{array}{l}074 \\
(2.35)\end{array}$ & $\begin{array}{c}17 \\
(5.67)\end{array}$ & $\begin{array}{c}11 \\
(3.67)\end{array}$ & $\begin{array}{r}112 \\
(3.25)\end{array}$ & $\begin{array}{c}085 \\
(2.46)\end{array}$ & $\begin{array}{c}13 \\
(5.20)\end{array}$ & $\begin{array}{c}08 \\
(3.20)\end{array}$ & $\begin{array}{r}125 \\
(3.38)\end{array}$ & $\begin{array}{r}093 \\
(2.51)\end{array}$ \\
\hline \multicolumn{2}{|c|}{ 3. Fowl cholera } & $\begin{array}{l}018 \\
(0.57)\end{array}$ & $\begin{array}{l}011 \\
(0.35)\end{array}$ & $\begin{array}{c}06 \\
(2.00)\end{array}$ & $\begin{array}{c}03 \\
(1.00)\end{array}$ & $\begin{array}{r}024 \\
(0.70)\end{array}$ & $\begin{array}{c}014 \\
(0.41)\end{array}$ & $\begin{array}{c}06 \\
(2.40)\end{array}$ & $\begin{array}{c}03 \\
(1.20)\end{array}$ & $\begin{array}{r}030 \\
(0.81)\end{array}$ & $\begin{array}{c}017 \\
(0.46)\end{array}$ \\
\hline \multicolumn{2}{|c|}{ 4. Infectious coryza } & $\begin{array}{l}018 \\
(0.57)\end{array}$ & $\begin{array}{l}009 \\
(0.29)\end{array}$ & $\begin{array}{c}05 \\
(1.67)\end{array}$ & $\begin{array}{c}03 \\
(1.00)\end{array}$ & $\begin{array}{r}023 \\
(0.35)\end{array}$ & $\begin{array}{c}012 \\
(0.00)\end{array}$ & $\begin{array}{c}06 \\
(2.40)\end{array}$ & $\begin{array}{c}03 \\
(1.20)\end{array}$ & $\begin{array}{r}029 \\
(0.78)\end{array}$ & $\begin{array}{r}015 \\
(0.41)\end{array}$ \\
\hline \multicolumn{2}{|c|}{ 5. Necrotic enteritis } & $\begin{array}{l}024 \\
(0.76)\end{array}$ & $\begin{array}{l}014 \\
(0.44)\end{array}$ & $\begin{array}{c}05 \\
(1.67)\end{array}$ & $\begin{array}{c}04 \\
(1.33)\end{array}$ & $\begin{array}{r}029 \\
(0.84)\end{array}$ & $\begin{array}{c}018 \\
(0.52)\end{array}$ & $\begin{array}{c}05 \\
(2.00)\end{array}$ & $\begin{array}{c}03 \\
(1.20)\end{array}$ & $\begin{array}{r}034 \\
(0.92)\end{array}$ & $\begin{array}{r}021 \\
(0.57)\end{array}$ \\
\hline B. & Viral diseases & $\begin{array}{l}\mathbf{2 3 1} \\
(7.33)\end{array}$ & $\begin{array}{l}\mathbf{1 6 3} \\
(5.17)\end{array}$ & $\begin{array}{c}\mathbf{5 1} \\
(17.00)\end{array}$ & $\begin{array}{c}28 \\
(9.33)\end{array}$ & $\begin{array}{r}282 \\
(8.17)\end{array}$ & $\begin{array}{r}191 \\
(5.54)\end{array}$ & $\begin{array}{c}\mathbf{4 0} \\
(16.00)\end{array}$ & $\begin{array}{c}24 \\
(9.60)\end{array}$ & $\begin{array}{r}322 \\
(8.70)\end{array}$ & $\begin{array}{r}215 \\
(5.81)\end{array}$ \\
\hline 6. & $\begin{array}{l}\text { Infectious bursal } \\
\text { disease }\end{array}$ & $\begin{array}{l}094 \\
(2.98)\end{array}$ & $\begin{array}{l}064 \\
(2.03)\end{array}$ & $\begin{array}{c}17 \\
(5.67)\end{array}$ & $\begin{array}{c}10 \\
(3.33)\end{array}$ & $\begin{array}{r}111 \\
(0.22)\end{array}$ & $\begin{array}{c}074 \\
(2.14)\end{array}$ & $\begin{array}{c}12 \\
(4.80)\end{array}$ & $\begin{array}{c}07 \\
(2.80)\end{array}$ & $\begin{array}{r}123 \\
(3.32)\end{array}$ & $\begin{array}{r}081 \\
(2.19)\end{array}$ \\
\hline & Newcastle disease & $\begin{array}{l}069 \\
(2.19)\end{array}$ & $\begin{array}{l}050 \\
(1.59)\end{array}$ & $\begin{array}{c}15 \\
(5.00)\end{array}$ & $\begin{array}{c}08 \\
(2.67)\end{array}$ & $\begin{array}{r}084 \\
(2.43)\end{array}$ & $\begin{array}{c}058 \\
(1.68)\end{array}$ & $\begin{array}{c}12 \\
(4.80)\end{array}$ & $\begin{array}{c}07 \\
(2.80)\end{array}$ & $\begin{array}{r}096 \\
(2.59)\end{array}$ & $\begin{array}{r}065 \\
(1.76)\end{array}$ \\
\hline & Avian leukosis & $\begin{array}{l}029 \\
(0.92)\end{array}$ & $\begin{array}{l}020 \\
(0.63)\end{array}$ & $\begin{array}{c}06 \\
(2.00)\end{array}$ & $\begin{array}{c}03 \\
(1.00)\end{array}$ & $\begin{array}{r}035 \\
(1.01)\end{array}$ & $\begin{array}{c}023 \\
(0.67)\end{array}$ & $\begin{array}{c}05 \\
(2.00)\end{array}$ & $\begin{array}{c}04 \\
(1.60)\end{array}$ & $\begin{array}{r}040 \\
(1.08)\end{array}$ & $\begin{array}{r}027 \\
(0.73)\end{array}$ \\
\hline & Fowl pox & $\begin{array}{l}018 \\
(0.57)\end{array}$ & $\begin{array}{l}012 \\
(0.38)\end{array}$ & $\begin{array}{c}07 \\
(2.33)\end{array}$ & $\begin{array}{c}04 \\
(1.33)\end{array}$ & $\begin{array}{r}025 \\
(0.72)\end{array}$ & $\begin{array}{c}016 \\
(0.46)\end{array}$ & $\begin{array}{c}05 \\
(2.00)\end{array}$ & $\begin{array}{c}03 \\
(1.20)\end{array}$ & $\begin{array}{r}030 \\
(0.81)\end{array}$ & $\begin{array}{r}019 \\
(0.51)\end{array}$ \\
\hline \multicolumn{2}{|c|}{ 10. Marek's disease } & $\begin{array}{l}021 \\
(0.66)\end{array}$ & $\begin{array}{l}017 \\
(0.53)\end{array}$ & $\begin{array}{c}06 \\
(2.00)\end{array}$ & $\begin{array}{c}03 \\
(1.00)\end{array}$ & $\begin{array}{r}027 \\
(0.78)\end{array}$ & $\begin{array}{c}020 \\
(0.58)\end{array}$ & $\begin{array}{c}06 \\
(2.40)\end{array}$ & $\begin{array}{c}03 \\
(1.20)\end{array}$ & $\begin{array}{r}033 \\
(0.89)\end{array}$ & $\begin{array}{r}023 \\
(0.62)\end{array}$ \\
\hline \multicolumn{2}{|c|}{ C. Fungal diseases } & $\begin{array}{l}\mathbf{0 8 8} \\
(2.79)\end{array}$ & $\begin{array}{l}\mathbf{0 6 1} \\
(1.94)\end{array}$ & $\begin{array}{c}17 \\
(5.67)\end{array}$ & $\begin{array}{c}11 \\
(3.67)\end{array}$ & $\begin{array}{r}105 \\
(3.04)\end{array}$ & $\begin{array}{r}\mathbf{0 7 2} \\
(2.09)\end{array}$ & $\begin{array}{c}15 \\
(6.00)\end{array}$ & $\begin{array}{c}\mathbf{0 9} \\
(3.60)\end{array}$ & $\begin{array}{r}120 \\
(3.24)\end{array}$ & $\begin{array}{r}\mathbf{0 8 1} \\
(2.19)\end{array}$ \\
\hline \multicolumn{2}{|c|}{ 11. Aspergillosis } & $\begin{array}{l}059 \\
(1.87)\end{array}$ & $\begin{array}{l}045 \\
(1.43)\end{array}$ & $\begin{array}{c}11 \\
(3.67)\end{array}$ & $\begin{array}{c}07 \\
(2.33)\end{array}$ & $\begin{array}{r}070 \\
(2.03)\end{array}$ & $\begin{array}{c}052 \\
(1.51)\end{array}$ & $\begin{array}{c}09 \\
(3.60)\end{array}$ & $\begin{array}{c}05 \\
(2.00)\end{array}$ & $\begin{array}{r}079 \\
(2.14)\end{array}$ & $\begin{array}{r}057 \\
(1.54)\end{array}$ \\
\hline \multicolumn{2}{|c|}{ 12. Aflatoxicosis } & $\begin{array}{l}029 \\
(0.92)\end{array}$ & $\begin{array}{l}016 \\
(0.51)\end{array}$ & $\begin{array}{c}06 \\
(2.00)\end{array}$ & $\begin{array}{c}04 \\
(1.33)\end{array}$ & $\begin{array}{r}035 \\
(1.01)\end{array}$ & $\begin{array}{c}020 \\
(0.58)\end{array}$ & $\begin{array}{c}06 \\
(2.40)\end{array}$ & $\begin{array}{c}04 \\
(1.60)\end{array}$ & $\begin{array}{r}041 \\
(1.11)\end{array}$ & $\begin{array}{r}024 \\
(0.65)\end{array}$ \\
\hline D. & Mycoplasmosis & $\begin{array}{l}\mathbf{0 8 1} \\
(2.57)\end{array}$ & $\begin{array}{l}\mathbf{0 5 4} \\
(1.71)\end{array}$ & $\begin{array}{c}15 \\
(5.00)\end{array}$ & $\begin{array}{c}\mathbf{0 8} \\
(2.67)\end{array}$ & $\begin{array}{r}\mathbf{0 9 6} \\
(2.78)\end{array}$ & $\begin{array}{r}\mathbf{0 6 2} \\
(1.80)\end{array}$ & $\begin{array}{c}14 \\
(5.60)\end{array}$ & $\begin{array}{c}\mathbf{0 8} \\
(3.20)\end{array}$ & $\begin{array}{r}110 \\
(2.97)\end{array}$ & $\begin{array}{r}\mathbf{0 7 0} \\
(1.89)\end{array}$ \\
\hline E. & Parasitic diseases & $\begin{array}{l}\mathbf{0 7 2} \\
(2.29)\end{array}$ & $\begin{array}{l}\mathbf{0 4 2} \\
(1.33)\end{array}$ & $\begin{array}{c}\mathbf{2 2} \\
(7.33)\end{array}$ & $\begin{array}{c}14 \\
(4.67)\end{array}$ & $\begin{array}{r}\mathbf{0 9 4} \\
(2.72)\end{array}$ & $\begin{array}{r}\mathbf{0 5 6} \\
(1.62)\end{array}$ & $\begin{array}{c}19 \\
(7.60)\end{array}$ & $\begin{array}{c}12 \\
(4.80)\end{array}$ & $\begin{array}{r}113 \\
(3.05)\end{array}$ & $\begin{array}{r}\mathbf{0 6 8} \\
(1.84)\end{array}$ \\
\hline \multicolumn{2}{|c|}{ 13. Ascaridiasis } & $\begin{array}{l}012 \\
(0.38)\end{array}$ & $\begin{array}{l}004 \\
(0.13)\end{array}$ & $\begin{array}{c}04 \\
(1.33)\end{array}$ & $\begin{array}{c}02 \\
(0.67)\end{array}$ & $\begin{array}{r}016 \\
(0.46)\end{array}$ & $\begin{array}{c}006 \\
(0.17)\end{array}$ & $\begin{array}{c}03 \\
(1.20)\end{array}$ & $\begin{array}{c}02 \\
(0.80)\end{array}$ & $\begin{array}{r}019 \\
(0.51)\end{array}$ & $\begin{array}{r}008 \\
(0.22)\end{array}$ \\
\hline \multicolumn{2}{|c|}{$\begin{array}{l}\text { 14. Tapeworm } \\
\text { infestation }\end{array}$} & $\begin{array}{l}008 \\
(0.25)\end{array}$ & $\begin{array}{l}003 \\
(0.10)\end{array}$ & $\begin{array}{c}02 \\
(0.67)\end{array}$ & $\begin{array}{c}02 \\
(0.67)\end{array}$ & $\begin{array}{r}010 \\
(0.29)\end{array}$ & $\begin{array}{c}005 \\
(0.14)\end{array}$ & $\begin{array}{c}02 \\
(0.80)\end{array}$ & $\begin{array}{c}01 \\
(0.40)\end{array}$ & $\begin{array}{r}012 \\
(0.32)\end{array}$ & $\begin{array}{r}006 \\
(0.16)\end{array}$ \\
\hline \multicolumn{2}{|c|}{ 15. Coccidiosis } & $\begin{array}{l}044 \\
(1.40)\end{array}$ & $\begin{array}{l}032 \\
(1.02)\end{array}$ & $\begin{array}{c}13 \\
(4.33)\end{array}$ & $\begin{array}{c}09 \\
(3.00)\end{array}$ & $\begin{array}{r}057 \\
(1.65)\end{array}$ & $\begin{array}{c}041 \\
(1.19)\end{array}$ & $\begin{array}{c}11 \\
(4.40)\end{array}$ & $\begin{array}{c}08 \\
(3.20)\end{array}$ & $\begin{array}{r}068 \\
(1.84)\end{array}$ & $\begin{array}{r}049 \\
(1.32)\end{array}$ \\
\hline \multicolumn{2}{|c|}{ 16. Ectoparasitosis } & $\begin{array}{l}008 \\
(0.25)\end{array}$ & $\begin{array}{l}003 \\
(0.10)\end{array}$ & $\begin{array}{c}03 \\
(1.00)\end{array}$ & $\begin{array}{c}01 \\
(0.33)\end{array}$ & $\begin{array}{r}011 \\
(0.32)\end{array}$ & $\begin{array}{c}004 \\
(0.12)\end{array}$ & $\begin{array}{c}03 \\
(1.20)\end{array}$ & $\begin{array}{c}01 \\
(0.40)\end{array}$ & $\begin{array}{r}014 \\
(0.38)\end{array}$ & $\begin{array}{r}005 \\
(0.14)\end{array}$ \\
\hline
\end{tabular}


Mortality and disease status in layer chickens

\begin{tabular}{|lcccccccccc|}
\hline F. Nutritional disorders & $\mathbf{1 1 2}$ & $\mathbf{0 6 5}$ & $\mathbf{2 0}$ & $\mathbf{1 2}$ & $\mathbf{1 3 2}$ & $\mathbf{0 7 7}$ & $\mathbf{2 5}$ & $\mathbf{1 5}$ & $\mathbf{1 5 7}$ & $\mathbf{0 9 2}$ \\
and others & $(3.56)$ & $(2.06)$ & $(6.67)$ & $(4.00)$ & $(3.83)$ & $(2.23)$ & $(10.00)$ & $(6.00)$ & $(4.24)$ & $(2.49)$ \\
17. Nutritional deficiency & 037 & 020 & 04 & 03 & 041 & 024 & 06 & 03 & 047 & 025 \\
& $(1.17)$ & $(0.63)$ & $(1.33)$ & $(1.00)$ & $(1.19)$ & $(0.70)$ & $(2.40)$ & $(1.20)$ & $(1.27)$ & $(0.68)$ \\
18. Ascites and HHS & 021 & 012 & 05 & 03 & 026 & 015 & 05 & 03 & 031 & 018 \\
& $(0.67)$ & $(0.38)$ & $(1.67)$ & $(1.00)$ & $(0.75)$ & $(0.43)$ & $(2.00)$ & $(1.20)$ & $(0.84)$ & $(0.49)$ \\
19. Cannibalism & 013 & 007 & 02 & 02 & 015 & 009 & 03 & 02 & 026 & 010 \\
& $(0.41)$ & $(0.22)$ & $(0.67)$ & $(0.80)$ & $(0.43)$ & $(0.26)$ & $(1.20)$ & $(0.80)$ & $(0.70)$ & $(0.27)$ \\
20. Egg bound disorders & 014 & 011 & 03 & 02 & 017 & 013 & 04 & 03 & 021 & 016 \\
& $(0.44)$ & $(0.35)$ & $(1.00)$ & $(0.67)$ & $(0.49)$ & $(0.38)$ & $(1.60)$ & $(1.20)$ & $(0.57)$ & $(0.43)$ \\
21. Egg peritonitis & 011 & 006 & 03 & 02 & 014 & 008 & - & - & 014 & 008 \\
& $(0.35)$ & $(0.19)$ & $(1.00)$ & $(0.67)$ & $(0.41)$ & $(0.23)$ & & & $(0.38)$ & $(0.22)$ \\
22. Heat stroke and & 016 & 009 & 03 & 02 & 019 & 011 & 07 & 04 & 026 & 015 \\
cold & $(0.51)$ & $(0.29)$ & $(1.00)$ & $(0.67)$ & $(0.55)$ & $(0.32)$ & $(2.80)$ & $(1.60)$ & $(0.70)$ & $(0.41)$ \\
\hline & 865 & 590 & 176 & 105 & 1041 & 695 & 157 & 093 & 1198 & 788 \\
Total & $(27.46)$ & $(18.73)$ & $(58.67)$ & $(35.00)$ & $(30.17)$ & $(20.14)$ & $(62.80)^{*}$ & $(37.20)^{*}$ & $(32.38)$ & $(21.30)$ \\
& & & & & & & & & & \multirow{2}{*}{$(0.38)$} \\
\end{tabular}

HHS $=$ Hydropericardium hepatitis syndrome $n=$ Number of birds $\quad * *$ Significant at $(p<0.01) *$ Insignificant $(p>0.05)$

The morbidity and mortality pattern in egg type chickens of different age groups caused by different diseases and disorders are presented in Table 3 . Of the 3700 population of chickens of the three farms, 1198 (32.38\%) birds of various ages were affected clinically of which $778(21.30 \%)$ layer birds died. This high mortality $(21.30 \%)$ in egg type chickens recorded in this study could be compared with the lower mortality reported by Farooq et al. (2002) who reported $6.67 \%$ mortality in egg type chickens. These losses were higher than that of the optimized level of mortality (8 to 10\%) reported by North and Bell (1990) in egg type layers for better profitability. The high mortality in egg type chickens could be attributed to outbreak of diseases, sub-standard management and health practices, poor quality of chicks or feed and filthy environment.

Etiological analysis of the recorded diseases and disorders showed highest mortality rate with bacterial diseases $(7.08 \%)$, followed by viral diseases $(5.81 \%)$, fungal diseases $(2.19 \%)$, mycoplasmosis $(1.89 \%)$, parasitic diseases $(1.84 \%)$ and nutritional disorders and others $(2.49 \%)$. Comparatively higher mortality rate have been reported by Rahman and Samad (2003) who reported 39.81\% bacterial diseases, $22.73 \%$ viral diseases, $13.65 \%$ mycoplasmosis, $10.11 \%$ parasitic diseases, $3.43 \%$ nutritional disorders and $1.54 \%$ fungal diseases. These differences might be due to differences of the experimental design. The present study was designed to detect the population mortality whereas Rahman and Samad (2003) who studied the case fatality rate in chickens in which dead birds were submitted for diagnosis in the laboratory.

The age-wise analysis on the overall mortality in chickens showed significantly $(\mathrm{p}<0.01)$ highest mortality in adult layers $(8.43 \%)$, followed by grower $(6.32 \%)$, pullets $(4.65 \%)$ and lowest in brooding chicks $(3.78 \%)$. These results support the findings of Rahman and Samad (2003) who reported highest mortality adult layers (45.52\%), followed by grower $(24.04 \%)$ and pullets $(18.16 \%)$ and lowest in brooding $(12.28 \%)$ chickens. Ghodasara et al. (1992) also reported relatively higher mortality rate during laying (49\%) than during the brooding $(26 \%)$ and growing period $(24 \%)$, resulting in poor performance. Farooq et al. (2002) reported higher mortality during brooding $(50.4 \%)$ and laying $(31.3 \%)$ than during growing $(18.3 \%)$ period. However, these variations might be due to variation of geo-climatic conditions, management status, litter or cage system of rearing, biosecurity status, immunization status, social awareness and moreover techniques used for the diagnosis and analysis of the data.

\section{Morbidity and mortality on strains of chickens}

The susceptibility to diseases and disorders between Hy-Line and ISA-Brown strains of chickens are presented in Table 3. The morbidity and mortality recorded in ISA-Brown strains (62.80\% and 37.20\%) were found 


\section{Z. Uddin and others}

significantly $(\mathrm{p}<0.01)$ higher in comparison to Hy-Line strain $(30.17 \%$ and $20.14 \%)$ chickens, respectively (Table 3 ). This study recorded $0.41 \%$ morbidity and $0.23 \%$ mortality caused by egg peritonitis in Hy-Line strain but not in ISA-Brown strain (Table 3). However, Farooq et al. (2002) reported higher mortality in Hy-Line and ISA-Brown strains than in Babcock and Nick-chickens. Petek (1999) and Tolimir and Masic (2000) also reported differences in mortality among various strains of egg type chickens.

\section{Bacterial diseases Salmonellosis}

Salmonellae caused Pullorum disease, Fowl typhoid, Fowl paratyphoid and other related infections in chickens (Hossain and Islam, 2004 and Samad, 2005). This study was recorded overall 3.14\% $(\mathrm{n}=116)$ mortality caused by salmonellosis. Higher mortality rate was recorded in adult layer chickens $(1.54 \%)$ in comparison to growing $(0.67 \%)$, pullet $(0.72 \%)$ and brooding $(0.51 \%)$ stages of birds (Table 4$)$. These results support the earlier reports of Giasuddin et al. (2002) who reported 5.56\% and Islam et al. (2003) reported 6.73\% mortality of chickens due to salmonellosis. Sasipreeyajan et al. (1996) isolated Salmonella from chicken litter (42\%), drinking water (36\%) and from feed troughs $(28 \%)$, and in addition, it is also recognized vertically transmitted disease. However, the mortality due to salmonellosis recorded in this study were lower than those reported by Giasuddin et al. (2002) and Islam et al. (2003) in Bangladesh and elsewhere by North and Bell (1990) who reported 50\% which might be due to indiscriminate use of antibiotics in flocks.

Significantly $(\mathrm{p}<0.01)$ higher mortality in layer birds due to salmonellosis were recorded during summer (1.22) in comparison to rainy (1.0\%) and winter $(0.92 \%)$ seasons (Table 5). These findings support the report of Rahman and Samad (2003) who reported highest case fatality rate due to salmonellosis in summer (48.05\%), followed by rainy $(28.31 \%)$ and lowest in winter $(23.66 \%)$ seasons. These findings indicate that salmonellosis is still an important disease problem in the poultry industry in Bangladesh.

\section{Colibacillosis}

Colibacillosis, caused by Escherichia coli is one of the most common bacterial diseases causing syndromes like air sacculitis, cellulitis, omphalitis, peritonitis, salpingitis, synovitis and coligranuloma. This study recorded an overall $2.51 \%$ mortality rate of colibacillosis in layer chickens which supports the earlier reports of Sarker (1976) reported 5.0\% and Talha et al. (2001) reported 5.51\% mortality rate due to colibacillosis in chickens in Bangladesh. Talha et al. (2001) and Rahman et al. (2004) reported higher proportinate prevalence rate of colibacillosis in growing chickens in comparison to adults whereas Bhattacharjee et al. (1996) reported widely prevalence of colibacillosis in both the brooding $(12.82 \%)$ and pre-production $(8.78 \%)$ and post-production (5.49\%). It also appears that the E. coli infection is widely prevalent (0.45 to $1.0 \%)$ in all age groups of chickens with high mortality rate in adult layer birds (Table 4). Qu et al. (1997) reported 5.5\% mortality and 10 to 20\% drop in egg production with $E$. coli infections in egg type layers reared in cage. Zenella et al. (2000) reported 5 to $10 \%$ mortality due to $E$. coli infection with no pronounced signs, suggesting that the infection may be there but couldn't be easily detected until regular tests are performed for its proper diagnosis. The situation leading to mortality with no pronounced clinical signs will be more critical as it wound result in heavier losses of reduced egg production prior to the investigations. E. coli is not only associated with reduction of egg production and mortality, it could be a pre-disposing factor for other concurrent infections like Infectious bursal disease, coccidiosis, mycoplasmosis and others (Singh et al., 1994; Prabhakaran et al., 1997; Rahman and Samad, 2003). Therefore, it is important to control E. coli infections in chickens, thereby preventing losses due to this disease and other associated infections.

\section{Fowl cholera}

Fowl cholera (FC) is one of the common bacterial diseases of layer birds, caused by Pasteurella multocida. and it has been reported as outbreak form in Bangladesh (Choudhury et al., 1985). This study was recorded as $0.46 \%$ mortality in layer chickens which support the earlier report of Bhattacharjee et al. (1996) who reported 1.98\% prevalence of Fowl cholera in layer chickens. In addition, Talha et al. (2001) reported 3.15\% and Giasuddin et al. (2002) reported $3.08 \%$ prevalence of Fowl cholera in chickens. 
Mortality and disease status in layer chickens

Table 4. Overall morbidity and mortality caused by diseases and disorders in layer birds in three layer farms

\begin{tabular}{|c|c|c|c|c|c|c|c|c|c|c|c|}
\hline \multirow[t]{2}{*}{$\mathrm{S} / \mathrm{N}$} & \multirow[t]{2}{*}{$\begin{array}{l}\text { Diseases and } \\
\text { disorders }\end{array}$} & \multicolumn{2}{|c|}{$\begin{array}{l}\text { Brooding } \\
\text { (Up to } 3 \mathrm{wks}) \\
(\mathrm{n}=3700)\end{array}$} & \multicolumn{2}{|c|}{$\begin{array}{l}\text { Growing } \\
(>3-8 \mathrm{wks}) \\
(\mathrm{n}=3560)\end{array}$} & \multicolumn{2}{|c|}{$\begin{array}{l}\text { Pullet } \\
(>8-20 \text { wks }) \\
(\mathrm{n}=3335)\end{array}$} & \multicolumn{2}{|c|}{$\begin{array}{l}\text { Layers } \\
(>20 \mathrm{wks}) \\
(\mathrm{n}=3180)\end{array}$} & \multicolumn{2}{|c|}{$\begin{array}{l}\text { Total } \\
(\mathrm{n}=3700)\end{array}$} \\
\hline & & $\begin{array}{l}\text { No. } \\
\text { sick }(\%)\end{array}$ & $\begin{array}{l}\text { No. } \\
\text { died }(\%)\end{array}$ & $\begin{array}{l}\text { No. } \\
\text { sick }(\%)\end{array}$ & $\begin{array}{l}\text { No. } \\
\text { died }(\%)\end{array}$ & $\begin{array}{l}\text { No. } \\
\text { sick }(\%)\end{array}$ & $\begin{array}{l}\text { No. } \\
\text { died }(\%)\end{array}$ & $\begin{array}{l}\text { No. } \\
\text { sick }(\%)\end{array}$ & $\begin{array}{l}\text { No. } \\
\text { died }(\%)\end{array}$ & $\begin{array}{l}\text { No. } \\
\text { sick }(\%)\end{array}$ & $\begin{array}{l}\text { No. } \\
\text { died }(\%)\end{array}$ \\
\hline A. & Bacterial & 64 & 39 & 94 & 64 & 75 & 55 & & & & \\
\hline 1. & Salmonellosis & 30 & 19 & 33 & 24 & 32 & 24 & $63 * *$ & $49^{*}$ & 158 & 116 \\
\hline & & $(0.81)$ & $(0.51)$ & $(0.93)$ & $(0.67)$ & $(0.96)$ & $(0.72)$ & $(1.98)$ & $(1.54)$ & $(4.27)$ & (3.11) \\
\hline 2. & Colibacillosis & $\begin{array}{c}28 \\
(0.76)\end{array}$ & $\begin{array}{c}17 \\
(0.46)\end{array}$ & $\begin{array}{c}37 \\
(1.04)\end{array}$ & $\begin{array}{l}27 \\
(0.76)\end{array}$ & $\begin{array}{c}19 \\
(0.57)\end{array}$ & $\begin{array}{c}17 \\
(0.51)\end{array}$ & $\begin{array}{c}41 \\
(1.29)\end{array}$ & $\begin{array}{l}32^{*} \\
(1.00)\end{array}$ & $\begin{array}{c}125 \\
(3.32)\end{array}$ & $\begin{array}{c}93 \\
(2.51)\end{array}$ \\
\hline 3. & Fowl Cholera & - & - & $\begin{array}{c}4 \\
(0.11)\end{array}$ & $\begin{array}{c}2 \\
(0.06)\end{array}$ & $\begin{array}{c}8 \\
(0.24)\end{array}$ & $\begin{array}{c}5 \\
(0.15)\end{array}$ & $\begin{array}{c}18 \\
(0.57)\end{array}$ & $\begin{array}{l}10^{*} \\
(0.31)\end{array}$ & $\begin{array}{c}30 \\
(0.81)\end{array}$ & $\begin{array}{c}17 \\
(0.46)\end{array}$ \\
\hline 4. & $\begin{array}{l}\text { Infectious } \\
\text { coryza }\end{array}$ & $\begin{array}{c}3 \\
(0.08)\end{array}$ & $\begin{array}{c}1 \\
(0.03)\end{array}$ & $\begin{array}{c}6 \\
(0.16)\end{array}$ & $\begin{array}{c}3 \\
(0.08)\end{array}$ & $\begin{array}{c}9 \\
(0.26)\end{array}$ & $\begin{array}{c}5 \\
(0.15)\end{array}$ & $\begin{array}{c}11 \\
(0.35)\end{array}$ & $\begin{array}{c}6^{*} \\
(0.19)\end{array}$ & $\begin{array}{c}29 \\
(0.78)\end{array}$ & $\begin{array}{c}15 \\
(0.40)\end{array}$ \\
\hline 5. & $\begin{array}{l}\text { Necrotic } \\
\text { enteritis }\end{array}$ & $\begin{array}{c}3 \\
(0.08)\end{array}$ & $\begin{array}{c}2 \\
(0.08)\end{array}$ & $\begin{array}{c}14 \\
(0.39)\end{array}$ & $\begin{array}{l}8^{*} \\
(0.22)\end{array}$ & $\begin{array}{c}7 \\
(0.21)\end{array}$ & $\begin{array}{c}4 \\
(0.12)\end{array}$ & $\begin{array}{c}10 \\
(0.31)\end{array}$ & $\begin{array}{c}7 * \\
(0.22)\end{array}$ & $\begin{array}{c}34 \\
(0.31)\end{array}$ & $\begin{array}{c}21 \\
(0.57)\end{array}$ \\
\hline B. & Viral diseases & $\begin{array}{c}80 \\
(2.16)\end{array}$ & $\begin{array}{c}55 \\
(1.49)\end{array}$ & $\begin{array}{c}87 \\
(2.44)\end{array}$ & $\begin{array}{l}59 \\
(1.66)\end{array}$ & $\begin{array}{c}70 \\
(2.10)\end{array}$ & $\begin{array}{c}43 \\
(1.29)\end{array}$ & $\begin{array}{r}86 \\
(2.70)\end{array}$ & $\begin{array}{l}58 \\
(1.82)\end{array}$ & $\begin{array}{c}322 \\
(8.70)\end{array}$ & $\begin{array}{r}215 \\
(5.81)\end{array}$ \\
\hline 6. & $\begin{array}{l}\text { Infectious bursal } \\
\text { disease }\end{array}$ & $\begin{array}{c}49 \\
(1.32)\end{array}$ & $\begin{array}{l}34 * * \\
(0.92)\end{array}$ & $\begin{array}{l}45 \\
(1.26)\end{array}$ & $\begin{array}{l}32 \\
(0.89)\end{array}$ & $\begin{array}{c}19 \\
(0.57)\end{array}$ & $\begin{array}{c}10 \\
(0.30)\end{array}$ & $\begin{array}{c}10 \\
(0.31)\end{array}$ & $\begin{array}{c}5 \\
(0.16)\end{array}$ & $\begin{array}{l}123 \\
(3.32)\end{array}$ & $\begin{array}{c}81 \\
(2.19)\end{array}$ \\
\hline & $\begin{array}{l}\text { Newcastle } \\
\text { disease }\end{array}$ & $\begin{array}{l}21 \\
(0.57)\end{array}$ & $\begin{array}{c}12 \\
(0.32)\end{array}$ & $\begin{array}{l}23 \\
(0.65)\end{array}$ & $\begin{array}{c}15 \\
(0.42)\end{array}$ & $\begin{array}{c}25 \\
(0.75)\end{array}$ & $\begin{array}{c}17 \\
(0.51)\end{array}$ & $\begin{array}{c}27 \\
(0.85)\end{array}$ & $\begin{array}{l}21^{*} \\
(0.66)\end{array}$ & $\begin{array}{l}96 \\
(2.56)\end{array}$ & $\begin{array}{c}65 \\
(1.76)\end{array}$ \\
\hline 8. & Avian leukosis & $\begin{array}{l}2 \\
(0.05)\end{array}$ & $\begin{array}{c}2 \\
(0.05)\end{array}$ & $\begin{array}{c}6 \\
(0.17)\end{array}$ & $\begin{array}{c}4 \\
(0.11)\end{array}$ & $\begin{array}{c}9 \\
(0.27)\end{array}$ & $\begin{array}{c}6 \\
(0.18)\end{array}$ & $\begin{array}{c}23 \\
(0.72)\end{array}$ & $\begin{array}{c}15^{*} \\
(0.47)\end{array}$ & $\begin{array}{c}40 \\
(1.08)\end{array}$ & $\begin{array}{c}27 \\
(0.79)\end{array}$ \\
\hline 9.1 & Fowl pox & $\begin{array}{c}4 \\
(0.11)\end{array}$ & $\begin{array}{c}4 \\
(0.11)\end{array}$ & $\begin{array}{c}8 \\
(0.22)\end{array}$ & $\begin{array}{c}4 \\
(0.11)\end{array}$ & $\begin{array}{r}9 \\
(0.27)\end{array}$ & $\begin{array}{r}5 \\
(0.15)\end{array}$ & $\begin{array}{r}10 \\
(0.31)\end{array}$ & $\begin{array}{c}6^{*} \\
(0.19)\end{array}$ & $\begin{array}{c}30 \\
(0.81)\end{array}$ & $\begin{array}{c}19 \\
(0.51)\end{array}$ \\
\hline & $\begin{array}{l}\text { Marek's } \\
\text { disease }\end{array}$ & $\begin{array}{c}4 \\
(0.11)\end{array}$ & $\begin{array}{c}3 \\
(0.08)\end{array}$ & $\begin{array}{c}5 \\
(0.14)\end{array}$ & $\begin{array}{c}4 \\
(0.11)\end{array}$ & $\begin{array}{c}8 \\
(0.24)\end{array}$ & $\begin{array}{c}5 \\
(0.15)\end{array}$ & $\begin{array}{l}16 \\
(0.50)\end{array}$ & $\begin{array}{l}11^{* *} \\
(0.35)\end{array}$ & $\begin{array}{c}33 \\
(0.89)\end{array}$ & $\begin{array}{c}23 \\
(0.62)\end{array}$ \\
\hline C. & Fungal diseases & $\begin{array}{c}25 \\
(0.68)\end{array}$ & $\begin{array}{c}16 \\
(0.42)\end{array}$ & $\begin{array}{l}55 \\
(1.54)\end{array}$ & $\begin{array}{l}41 * * \\
(1.15)\end{array}$ & $\begin{array}{r}24 \\
(0.72)\end{array}$ & $\begin{array}{r}13 \\
(0.39)\end{array}$ & $\begin{array}{c}16 \\
(0.50)\end{array}$ & $\begin{array}{c}11 \\
(0.35)\end{array}$ & $\begin{array}{r}120 \\
(3.24)\end{array}$ & $\begin{array}{c}81 \\
(2.19)\end{array}$ \\
\hline 11. & Aspergillosis & $\begin{array}{c}17 \\
(0.46)\end{array}$ & $\begin{array}{c}10 \\
(0.27)\end{array}$ & $\begin{array}{l}43 \\
(1.21)\end{array}$ & $\begin{array}{l}35 * * \\
(0.98)\end{array}$ & $\begin{array}{c}13 \\
(0.39)\end{array}$ & $\begin{array}{c}8 \\
(0.24)\end{array}$ & $\begin{array}{c}6 \\
(0.19)\end{array}$ & $\begin{array}{c}4 \\
(0.13)\end{array}$ & $\begin{array}{c}79 \\
(2.13)\end{array}$ & $\begin{array}{c}57 \\
(1.54)\end{array}$ \\
\hline 12. & Aflatoxicosis & $\begin{array}{c}8 \\
(0.22)\end{array}$ & $\begin{array}{c}6 \\
(0.16)\end{array}$ & $\begin{array}{c}12 \\
(0.34)\end{array}$ & $\begin{array}{c}6 \\
(0.17)\end{array}$ & $\begin{array}{c}11 \\
(0.33)\end{array}$ & $\begin{array}{c}5 \\
(0.15)\end{array}$ & $\begin{array}{c}10 \\
(0.31)\end{array}$ & $\begin{array}{c}7 * \\
(0.22)\end{array}$ & $\begin{array}{c}41 \\
(1.10)\end{array}$ & $\begin{array}{c}24 \\
(0.65)\end{array}$ \\
\hline D. & Mycoplasmosis & $\begin{array}{l}\mathbf{1 9} \\
(0.51)\end{array}$ & $\begin{array}{c}12 \\
(0.32)\end{array}$ & $\begin{array}{c}30 \\
(0.84)\end{array}$ & $\begin{array}{c}17 \\
(0.48)\end{array}$ & $\begin{array}{c}25 \\
(0.75)\end{array}$ & $\begin{array}{c}17 \\
(0.51)\end{array}$ & $\begin{array}{l}\mathbf{3 6} \\
(1.13)\end{array}$ & $\begin{array}{r}\mathbf{2 4 *} \\
(0.75)\end{array}$ & $\begin{array}{r}110 \\
(2.97)\end{array}$ & $\begin{array}{c}70 \\
(1.89)\end{array}$ \\
\hline E. & Parasitic diseases & $\begin{array}{ll}5 & 1 \\
& (0.14)\end{array}$ & $\begin{array}{c}39 \\
\quad(0.03)\end{array}$ & $\begin{array}{c}30 \\
(1.10)\end{array}$ & $\begin{array}{c}22 \\
(0.84)\end{array}$ & $\begin{array}{c}9 \\
(0.66)\end{array}$ & $\begin{array}{r}47 * \\
(0.27)\end{array}$ & $\begin{array}{l}28 * \\
(1.48)\end{array}$ & $\begin{array}{l}113 \\
(0.88)\end{array}$ & $\begin{array}{c}68 \\
(3.05)\end{array}$ & $(\mathbf{1 . 8 4})$ \\
\hline 13. & Ascaridiasis & $\begin{array}{c}5 \\
(0.14)\end{array}$ & $\begin{array}{c}1 \\
(0.03)\end{array}$ & $\begin{array}{c}4 \\
(0.11)\end{array}$ & $\begin{array}{c}3 \\
(0.08)\end{array}$ & $\begin{array}{c}4 \\
(0.12)\end{array}$ & $\begin{array}{c}1 \\
(0.03)\end{array}$ & $\begin{array}{l}6 \\
(0.19)\end{array}$ & $\begin{array}{c}3 \\
(0.09)\end{array}$ & $\begin{array}{c}19 \\
(0.51)\end{array}$ & $\begin{array}{c}8 \\
(0.22)\end{array}$ \\
\hline 14. & $\begin{array}{l}\text { Tapeworm } \\
\text { infestation }\end{array}$ & - & - & $\begin{array}{c}2 \\
(0.06)\end{array}$ & $\begin{array}{c}1 \\
(0.03)\end{array}$ & $\begin{array}{c}4 \\
(0.12)\end{array}$ & $\begin{array}{c}1 \\
(0.03)\end{array}$ & $\begin{array}{l}6 \\
(0.19)\end{array}$ & $\begin{array}{c}4 \\
(0.13)\end{array}$ & $\begin{array}{c}12 \\
(0.32)\end{array}$ & $\begin{array}{c}6 \\
(0.16)\end{array}$ \\
\hline 15. & Coccidiosis & - & - & $\begin{array}{c}31 \\
(0.87)\end{array}$ & $\begin{array}{r}25 * * \\
(0.70)\end{array}$ & $\begin{array}{c}10 \\
(0.30)\end{array}$ & $\begin{array}{c}6 \\
(0.18)\end{array}$ & $\begin{array}{l}27 \\
(0.85)\end{array}$ & $\begin{array}{c}18 \\
(0.57)\end{array}$ & $\begin{array}{c}68 \\
(1.83)\end{array}$ & $\begin{array}{c}49 \\
(1.32)\end{array}$ \\
\hline 16. & $\begin{array}{l}\text { Ectoparasitic } \\
\text { infestation }\end{array}$ & - & - & $\begin{array}{c}2 \\
(0.06)\end{array}$ & $\begin{array}{c}1 \\
(0.03)\end{array}$ & $\begin{array}{c}4 \\
(0.12)\end{array}$ & $\begin{array}{c}1 \\
(0.03)\end{array}$ & $\begin{array}{l}8 \\
(0.25)\end{array}$ & $\begin{array}{c}3 \\
(0.09)\end{array}$ & $\begin{array}{c}14 \\
(0.37)\end{array}$ & $\begin{array}{c}5 \\
(0.14)\end{array}$ \\
\hline F. & $\begin{array}{l}\text { Nutritional } \\
\text { deficiency \& other }\end{array}$ & $\begin{array}{c}31 \\
\text { ers }(\mathbf{0 . 8 4})\end{array}$ & $\begin{array}{c}17 \\
(0.46)\end{array}$ & $\begin{array}{c}24 \\
(0.67)\end{array}$ & $\begin{array}{c}14 \\
(0.39)\end{array}$ & $\begin{array}{c}29 \\
(0.87)\end{array}$ & $\begin{array}{c}18 \\
(0.54)\end{array}$ & $\begin{array}{l}73 * * \\
(2.30)\end{array}$ & $\begin{array}{c}43 \\
(1.35)\end{array}$ & $\begin{array}{c}157 \\
(4.24)\end{array}$ & $\begin{array}{c}92 \\
(2.49)\end{array}$ \\
\hline
\end{tabular}




\begin{tabular}{|c|c|c|c|c|c|c|c|c|c|c|}
\hline $\begin{array}{l}\text { 17. Nutritional } \\
\text { deficiency }\end{array}$ & $\begin{array}{c}18 \\
(0.49)\end{array}$ & $\begin{array}{r}9 \\
(0.24)\end{array}$ & $\begin{array}{c}10 \\
(0.28)\end{array}$ & $\begin{array}{c}7 \\
(0.20)\end{array}$ & $\begin{array}{c}7 \\
(0.21)\end{array}$ & $\begin{array}{c}4 \\
(0.12)\end{array}$ & $\begin{array}{c}12 \\
(0.38)\end{array}$ & $\begin{array}{c}5 \\
(0.16)\end{array}$ & $\begin{array}{c}47 \\
(1.27)\end{array}$ & $\begin{array}{l}25 \\
(0.68)\end{array}$ \\
\hline $\begin{array}{l}\text { 18. Ascites and } \\
\text { HHS }\end{array}$ & $\begin{array}{c}8 \\
(0.22)\end{array}$ & $\begin{array}{r}5 \\
(0.14)\end{array}$ & $\begin{array}{c}5 \\
(0.14)\end{array}$ & $\begin{array}{c}3 \\
(0.08)\end{array}$ & $\begin{array}{c}6 \\
(0.18)\end{array}$ & $\begin{array}{c}4 \\
(0.12)\end{array}$ & $\begin{array}{c}12 \\
(0.38)\end{array}$ & $\begin{array}{c}6 \\
(0.19)\end{array}$ & $\begin{array}{c}31 \\
(0.83)\end{array}$ & $\begin{array}{c}18 \\
(0.49)\end{array}$ \\
\hline 19. Cannibalism & - & - & $\begin{array}{c}2 \\
(0.06)\end{array}$ & $\begin{array}{c}1 \\
(0.03)\end{array}$ & $\begin{array}{c}5 \\
(0.15)\end{array}$ & $\begin{array}{c}3 \\
(0.09)\end{array}$ & $\begin{array}{c}11 \\
(0.35)\end{array}$ & $\begin{array}{c}6 \\
(0.19)\end{array}$ & $\begin{array}{c}26 \\
(0.70)\end{array}$ & $\begin{array}{c}10 \\
(0.27)\end{array}$ \\
\hline 20. Egg peritonitis & - & - & - & - & & & $\begin{array}{c}14 \\
(0.44)\end{array}$ & $\begin{array}{c}8 \\
(0.25)\end{array}$ & $\begin{array}{c}16 \\
(0.44)\end{array}$ & $\begin{array}{c}8 \\
(0.22)\end{array}$ \\
\hline $\begin{array}{l}\text { 21. Egg bound } \\
\text { disorder }\end{array}$ & - & - & - & - & & & $\begin{array}{c}21 \\
(0.66)\end{array}$ & $\begin{array}{c}16 \\
(0.50)\end{array}$ & $\begin{array}{c}21 \\
(0.56)\end{array}$ & $\begin{array}{c}16 \\
(0.43)\end{array}$ \\
\hline $\begin{array}{l}\text { 22. Heat stroke } \\
\text { and cold }\end{array}$ & $\begin{array}{c}5 \\
(0.14)\end{array}$ & $\begin{array}{c}3 \\
(0.08)\end{array}$ & $\begin{array}{c}7 \\
(0.20)\end{array}$ & $\begin{array}{c}3 \\
(0.08)\end{array}$ & $\begin{array}{c}5 \\
(0.15)\end{array}$ & $\begin{array}{c}3 \\
(0.09)\end{array}$ & $\begin{array}{c}9 \\
(0.28)\end{array}$ & $\begin{array}{c}6 \\
(0.19)\end{array}$ & $\begin{array}{c}26 \\
(0.70)\end{array}$ & $\begin{array}{c}15 \\
(0.40)\end{array}$ \\
\hline Total & $\begin{array}{c}223 \\
(6.03)\end{array}$ & $\begin{array}{l}140 \\
(3.78)\end{array}$ & $\begin{array}{c}329 \\
(9.24)\end{array}$ & $\begin{array}{c}225 \\
(6.32)\end{array}$ & $\begin{array}{c}245 \\
(7.35)\end{array}$ & $\begin{array}{l}155 \\
(4.65)\end{array}$ & $\begin{array}{l}401 \\
(12.61)\end{array}$ & $\begin{array}{r}268 * * \\
(8.43)\end{array}$ & $\begin{array}{l}1198 \\
(32.38)\end{array}$ & $\begin{array}{c}788 \\
(21.30)\end{array}$ \\
\hline
\end{tabular}

HHS = Hydropericardium hepatitis syndrome $\quad \mathrm{n}=$ No. of birds $\quad * *=$ Significant at $(\mathrm{p}<.01) *$ Insignificant $(\mathrm{p}>0.05)$

This disease was recorded in chickens of more than 3 weeks of age in all the three layer farms with significantly $(\mathrm{p}<0.01)$ highest mortality $(0.31 \%)$ in adult layer chickens (Table 4$)$. This observation is in conformity with the earlier report of Choudhury et al. (1985) who reported FC in chickens aged between 6 to 12 months old, Talha et al. (2001) reported FC in chickens from more than 2 weeks of old with highest incidence in adult (> 20 weeks birds) and Rahman et al. (2004) who reported FC in chickens more than two weeks of age with significantly $(\mathrm{p}<0.01)$ highest occurrence in adult layer chickens.

Seasonal influence on mortality of FC in chickens showed significantly $(\mathrm{p}<0.01)$ highest mortality during summer $(0.24 \%)$ in comparison to rainy $(0.14 \%)$ and winter $(0.08 \%)$ seasons (Table 5). These results support the reports of Bhattacharjee et al. (1996) who reported higher infection rate during March to July, and Rahman et al. (2004) reported higher infection during summer (49.12\%) in comparison to rainy $(26.32 \%)$ and winter $(24.56 \%)$ seasons.

\section{Infectious coryza}

Infectious coryza (IC), caused by Haemophilus paragallinarum characterized by conjunctivitis, oculo-nasal discharge, swelling of the infra-orbital sinuses and edema of the face, and severe drop in egg production which was recorded only in $15(0.41 \%)$ chickens (Table 4$)$. Significantly $(\mathrm{p}<0.01)$ highest mortality was recorded in adult layers $(0.19 \%)$, followed by pullets $(0.15 \%)$, growing $(0.08 \%)$ and brooding $(0.03 \%)$ chickens (Table 4$)$. The highest mortality due to IC was during summer $(0.19 \%)$, followed by winter $(0.14 \%)$ and rainy $(0.08 \%)$ season. These observations are in conformity with the report of Talha et al. (2001) who reported $0.52 \%$ proportionate incidence rate, of which one case aged between more than 2 to 8 weeks and other case aged $>20$ weeks old. Similarly, Ghodasara et al. (1992) and Anjaneyulu (1998) reported $0.41 \%$ and $9.6 \%$ incidence of this disease respectively.

\section{Necrotic enteritis}

Necrotic enteritis (NE) is an acute bacterial disease of chickens caused by Clostridium perfringens characterized by sudden death, friable and distended intestines and severe necrosis of the intestinal mucosa. This study recorded $0.57 \%$ mortality due to NE in chickens, of which $0.22 \%$ in growing, $0.22 \%$ in adult layer, $0.12 \%$ in pullet and $0.08 \%$ in brooding chickens. The significantly $(\mathrm{p}<0.01)$ highest mortality due to NE was recorded during summer $(0.24 \%)$ in comparison to winter $(0.19 \%)$ and rainy $90.14 \%$ ) season (Table 5). These results support the reports of Bhattacharjee et al. (1996) who reported 1.38\% and Rahman et al. (2004) reported $1.37 \%$ NE in chickens. 
Table 5. Season-wise mortality of egg type layer chickens

\begin{tabular}{|c|c|c|c|c|}
\hline $\begin{array}{ll}\text { S/N } & \begin{array}{l}\text { Diseases and } \\
\text { disorders }\end{array}\end{array}$ & $\begin{array}{l}\text { Summer } \\
\text { (March to June) } \\
(\mathrm{n}=3700) \\
\text { No. died }(\%)\end{array}$ & $\begin{array}{l}\text { Rainy } \\
\text { (July to Oct.) } \\
(\mathrm{n}=3700) \\
\text { No. died }(\%)\end{array}$ & $\begin{array}{l}\text { Winter } \\
\text { (Nov. to Feb.) } \\
(\mathrm{n}=3700) \\
\text { No. died }(\%)\end{array}$ & $\begin{array}{l}\text { Total } \\
\text { (March to Feb.) } \\
(\mathrm{n}=3700) \\
\text { No. died }(\%)\end{array}$ \\
\hline A. Bacterial diseases & $107(2.89)$ & $71(1.92)$ & $84(2.27)$ & $262(7.08)$ \\
\hline 1.Salmonellosis & $045(1.22)^{* *}$ & $37(1.00)$ & $34(0.92)$ & $116(3.14)$ \\
\hline 2.Colibacillosis & $037(1.00)^{* *}$ & $21(0.57)$ & $35(0.95)$ & $093(2.51)$ \\
\hline 3.Fowl cholera & $009(0.24)^{* *}$ & $05(0.14)$ & $03(0.08)$ & $017(0.46)$ \\
\hline 4.Infectious coryza & $007(0.19)^{* *}$ & $03(0.08)$ & $05(0.14)$ & $015(0.41)$ \\
\hline 5.Necrotic enteritis & $009(0.24)^{* *}$ & $05(0.14)$ & $07(0.19)$ & $021(0.57)$ \\
\hline B. Viral diseases & $091(2.46)$ & $60(1.62)$ & $63(1.70)$ & $215(5.81)$ \\
\hline 6.Infectious bursal disease & $040(1.08)^{* *}$ & $22(0.59)$ & $19(0.51)$ & $081(2.19)$ \\
\hline 7.Newcastle disease & $026(0.70)^{* *}$ & $20(0.54)$ & $19(0.51)$ & $065(1.76)$ \\
\hline 8.Avian leukosis & $008(0.22)$ & $07(0.19)$ & $12(0.32)^{* *}$ & $027(0.73)$ \\
\hline 9.Fowl pox & $008(0.22)^{* *}$ & $05(0.14)$ & $06(0.16)$ & $019(0.51)$ \\
\hline 10. Marek's disease & $009(0.24)^{* *}$ & $06(0.16)$ & $07(0.19)$ & $023(0.62)$ \\
\hline C. Fungal diseases & $016(0.43)$ & $42(1.14)$ & $23(0.62)$ & $081(2.19)$ \\
\hline 11. Aspergillosis & $009(0.24)$ & $30(0.81)$ & $18(0.49)$ & $057(1.54)$ \\
\hline 12. Aflatoxicosis & $007(0.19)$ & $12(0.32)^{* *}$ & $05(0.14)$ & $024(0.65)$ \\
\hline D. Mycoplasmosis & $041(1.11)^{* *}$ & $14(0.38)$ & $15(0.41)$ & $070(1.89)$ \\
\hline E. Parasitic diseases & $021(0.57)$ & $16(0.43)$ & $31(0.84)$ & $068(1.84)$ \\
\hline 13. Ascaridiais & $003(0.08)^{*}$ & $02(0.05)$ & $03(0.08)$ & $008(0.22)$ \\
\hline 14. Tapeworm infestation & $001(0.03)$ & $03(0.08)^{* *}$ & $02(0.05)$ & $006(0.16)$ \\
\hline 15. Coccidiosis & $016(0.43)$ & $10(0.27)$ & $23(0.62)^{* *}$ & $049(1.32)$ \\
\hline 16. Ectoparasitosis & $001(0.03)$ & $01(0.03)$ & $03(0.08)^{* *}$ & $005(0.14)$ \\
\hline F. Nutritional disorders & $040(1.08)$ & $27(0.73)$ & $25(0.68)$ & $092(2.49)$ \\
\hline 17. Nutritional deficiency & $009(0.24)$ & $10(0.27)$ & $06(0.16)$ & $025(0.68)$ \\
\hline 18. Ascites and HHS & $009(0.24)$ & $05(0.14)$ & $04(0.11)$ & $018(0.49)$ \\
\hline 19. Cannibalism & $004(0.11)$ & $03(0.08)$ & $03(0.08)$ & $010(0.27)$ \\
\hline 20. Egg bound disorder & $009(0.24) * *$ & $03(0.08)$ & $04(0.11)$ & $016(0.43)$ \\
\hline 21. Egg peritonitis & $003(0.08)^{*}$ & $02(0.05)$ & $03(0.08)^{*}$ & $008(0.22)$ \\
\hline 22. Heat stroke and cold & $006(0.16)^{* *}$ & $04(0.11)$ & $05(0.14)$ & $015(0.41)$ \\
\hline Total & $317(8.57)$ & $230(6.22)$ & $241(6.51)$ & $788(21.30)$ \\
\hline
\end{tabular}

$\mathrm{n}=$ No. of birds died $\quad * *$ Significant $(\mathrm{p}<0.01) \quad *$ Significant $(\mathrm{p}<0.05)$

The occurrence of NE in chickens more than 3 weeks old with highest mortality rate in growing chickens ( $>3$ to 8 weeks) also is in conformity with the report of Das et al. (2001) who reported its highest incidence in 4 weeks old birds. Dewan and Das (1989) reported NE in pullets of 4 months (16 weeks) old birds. The highest mortality due to NE during summer $(0.24 \%)$ and lowest during rainy $(0.14 \%)$ seasons are in partly support with the report of Kim et al. (1996) who reported higher prevalence of NE during summer (52.40\%) in comparison to winter $(4.5 \%)$ season. 


\section{Z. Uddin and others}

\section{Viral diseases \\ Infectious bursal disease}

Infectious bursal disease (IBD), also known as Gumboro disease is an acute contagious viral disease of young chickens characterized by diarrhea, vent picking, trembling, incoordination, swelling followed by atrophy of bursa of Fabricius and a variable degrees of immuno-suppression (Sah et al., 1995; Samad, 2005). This study recorded $3.32 \%$ morbidity and $2.19 \%$ mortality rates in chickens due to IBD (Table 4), and this result supports the report of Farooq et al. (2002) who reported $1.08 \%$ mortality rate due to IBD. However, this result contradict the earlier inland reports of Bhattacharjee et al. (1996), Talha et al. (2001) and Giasuddin et al. (2002) who reported $10.99 \%, 19.16 \%$ and $12.0 \%$ mortality in chickens caused by IBD, respectively. This difference could be due to case fatality rate reported by these authors. It indicates that the decreased mortality in chickens due to IBD recorded in this study might be due to use of vaccines in these selected flocks (Table 4). But the outbreak of this disease has been reported in both the vaccinated and non-vaccinated birds (Islam and Samad, 2003). However, Gumbooro disease had also been reported to cause heavier losses in chickens elsewhere $(10-75 \%, 36.65 \%$ Singh et al., 1994; 20\%, Rao et al., 1990). Although the IBD recorded in all the four age groups of chickens but significantly $(\mathrm{p}<0.01)$ highest mortality rate was recorded in brooding aged up to 3 weeks $(0.92 \%)$, followed by growing $(0.89 \%)$ chickens which are in conformity with the earlier reports of Talha et al. (2001) who reported highest infection rate in birds aged between $>2$ to 8 weeks. These results also support the global reports (3276\%, Philip and Moitra, 1993; 20\%, Rao et al., 1990; 25\%, Prabhakaran et al., 1997) who reported higher mortality rates in between the age of 2 to 12 weeks than at any other stage of life. However, Philip and Moitra (1993) reported unexpectedly higher losses due to IBD in chickens at the age of 17 weeks.

Although the IBD was recorded in all the four age groups of chickens but significantly $(\mathrm{p}<0.01)$ highest mortality rate was recorded in brooding aged up to 3 weeks $(0.92 \%)$, followed by growing $(0.89 \%)$ chickens which are in conformity with the earlier report of Talha et al. (2001) who reported highest infection rate in birds aged between $>2$ to 8 weeks. Although the IBD was recorded all the seasons of the year but significantly $(\mathrm{p}<0.01)$ highest mortality rate was recorded during summer $(1.08 \%)$ in comparison to rainy $(0.59 \%)$ and winter $(0.51 \%)$ seasons.

\section{Newcastle disease}

Newcastle disease (ND) is an acute viral disease of chickens associated with high morbidity and mortality in Bangladesh (Chowdhury et al., 198; Samad, 2000). This study recorded an overall $2.56 \%$ morbidity and $1.76 \%$ mortality in egg type chickens caused by ND. Mortality $(1.76 \%)$ due to ND recorded in this study is found lower than rates reported from Bangladesh by Talha et al. (2001), Giasuddin et al. (2002), Rahman and Samad (2003) who reported $10.24 \%, 8.0 \%$ and $10.34 \%$ mortality due to ND, respectively. The comparatively lower losses recorded in this study could probably be attributed to the implementation of effective measures for the prevention of diseases by vaccination and maintenance of improved hygienic condition in cage system. However, ND infection occurred despite that these infected flocks were vaccinated 3 to 4 times against the disease (Siddique $e t$ al., 1986; Babiker et al., 2009).

Although the ND was recorded in all the age groups of chickens but this study recorded highest mortality rate in chickens aged more than 20 weeks $(0.66 \%)$. This observation is somewhat contradict with the report of Talha et al. (2001) who reported highest prevalence rate in chickens aged between $>2$ to 8 weeks. But this finding supports the report of Parimal and Balasubramanian (1992) and Rahman and Samad (2003) who reported highest incidence of ND in 2 to 6 months and above 6 months old chickens, with highest mortality in 24 weeks age and < 7 weeks of old chickens, respectively.

ND was recorded in all seasons of the years with significantly $(\mathrm{p}<0.01)$ higher during summer $(0.70 \%)$ in comparison to rainy $(0.54 \%)$ and winter $(0.51 \%)$ seasons.

\section{Avian leukosis}

It is a neoplastic disease caused by retrovirus, which is characterized by a gradual onset in a flock, persistent low mortality and neoplasm of the internal organ especially in a flock, persistent low mortality and neoplasm of the internal organs especially the liver, spleen and kidney as reported by Mosleuddin et al. (1972). Only 0.73\% mortality was recorded of which $0.47 \%$ recognized in layers ( $>20$ weeks old) and $0.18 \%$ in both pullet and in growing $0.11 \%$ chickens. These observations support the earlier reports of Kamal and Hossain (1992), 
Bhattacharjee et al. (1996) and Talha et al. (2001) who reported 1.93\%, 6.92\% and 1.57\% proportionate incidence of AL in chickens, respectively. Rahman and Samad (2003) reported 0.34\% AL in Gazipur district. Age-wise mortality due to AI in chickens recorded in this study supports the earlier report of Talha et al. (2001) who reported highest mortality in $>8$ to 20 weeks and in $>20$ weeks old chickens. Although the AL was recorded in all the three seasons of the year but significantly $(\mathrm{p}<0.01)$ highest mortality rate was recorded during winter $(0.32 \%)$ in comparison to summer $(0.22 \%)$ and rainy $(0.19 \%)$ seasons.

\section{Fowl pox}

Fowl pox (FP) is an important viral disease in chickens, characterized by cutaneous and diphtheritic lesions in the upper digestive and respiratory tracts. This study recorded $0.81 \%(\mathrm{n}=30)$ morbidity and $0.51 \%(\mathrm{n}=23)$ mortality in chickens (Table 4). Significantly $(\mathrm{p}<0.01)$ highest mortality was recorded during summer $(0.22 \%)$ in comparison to winter $(00.16 \%)$ and rainy $(0.14 \%)$ seasons (Table 5). Some research works on FP vaccine and vaccination have been reported from Bangladesh (Samad, 2000) but the reports on other aspects are limited in inland literature.

\section{Marek's disease}

The overall mortality due to Marek's disease was recorded in $0.62 \%(\mathrm{n}=23)$ chickens. Highest mortality rate of $0.35 \%(n=11)$ was found in laying hens. The occurrence of Marek's disease has been reported from Bangladesh (Mosleuddin and Dewan, 1974) but detail studies on MD are not available in inland literature (Samad, 2000). However, Al-Sadi et al. (2000) reported 5.70\% incidence of MD in laying chickens in Iraq. Highest mortality of $0.24 \%$ was recorded in summer, followed by $0.19 \%$ in winter and $0.16 \%$ in rainy seasons.

\section{Avian mycoplasmosis}

Mycoplasma gallisepticum is considered the primary cause of chronic respiratory disease (CRD) and other organisms frequently caused complications, transmitted with horizontally and vertically and characterized by respiratory signs and lesions and a prolonged course in the flock Biswas et al., 1993; Samad, 2005). This study recorded $1.89 \%(n=70)$ mortality due to mycoplasmosis in chickens (Table 4$)$. The mortality rate of $1.89 \%$ in layer chickens due to CRD recorded in this study supports the report of Babiker et al. (2009) who reported 1.11 to $1.45 \%$ mortality of layer chickens due to CRD. However, these reports contradicts with inland reports of Talha et al. (2001) and Giasuddin et al. (2002) who reported $11.55 \%$ and $9.0 \%$ case fatality rates of mycoplasmosis in chickens from Bangladesh. Rahman and Samad (2003) reported 13.65\% case fatality rate due to mycoplasmosis in Gazipur districts. Age-wise mortality of mycoplasmosis showed higher mortality in adult layer $(0.75 \%)$ in comparison to $>3$ to $8(0.48 \%)$ weeks and $>8$ to 20 weeks $(0.51 \%)$ and up to 3 weeks $(0.32 \%)$ aged chickens (Table 4). These findings support the earlier reports of Rahman and Samad (2003) who reported higher case fatality rate incidence in adult layer whereas Talha et al. (2001) reported higher case fatality rate in grower ( $>2$ to 8 weeks) chickens.

The mortality due to mycoplasmosis was highest during summer $(1.11 \%)$, followed by winter $(0.41 \%)$ and rainy $(0.38 \%)$ seasons (Table 5). These findings correlate with the results of Rahman and Samad (2003) who reported higher case fatality rate of mycoplasmosis during summer months.

\section{Fungal diseases}

Aspergillus fumigatus is the main causal agent of aspergillosis in avian species which has been reported from Bangladesh (Samad and Chakraborty, 1993a). An overall 1.54\% ( $\mathrm{n}=57$ ) mortality due to aspergillosis was recorded in chickens which supports with the reports of Talha et al. (2001), Rahman and Samad (2003) who reported $4.20 \%$ and $1.09 \%$ mortality in chickens due to aspergillosis, respectively.

Mortality in chickens caused by aspergillosis was recorded highest in growing ( $>3$ to 8 weeks old) chickens $(0.98 \%)$ in comparison to other age groups of chickens (Table 4). Seasonal mortality due to aspergillosis was recorded highest during rainy $(0.81 \%)$ in comparison to winter $(0.49 \%)$ and summer $(0.24 \%)$ seasons (Table 5). These findings support the results of Rahman and Samad (2003) and Mahajan et al. (1994) who reported highest incidence of brooder pneumonia during hot and humid weather. 


\title{
M. Z. Uddin and others
}

\begin{abstract}
Aflatoxicosis
Aflatoxicosis is one of the major issues in chicken production, which occurs due to contaminated feed, resulting in higher mortality and severe drop in egg production. This study recorded an overall $0.65 \%(\mathrm{n}=24)$ mortality in chickens which support the earlier reports of Rahman and Samad (2003) who reported 0.46\%, Talha et al. (2001) reported $0.52 \%$, and Bhattacharjee et al. (1996) reported $1.76 \%$ aflatoxicosis in chickens. The highest mortality rate was recorded in layer birds $(0.22 \%)$, followed by brooding $(0.16 \%)$, growing $(0.17 \%)$ and pullet $(0.15 \%)$ birds. Aflatoxicosis caused highest mortality was recorded during rainy $(0.32 \%)$, followed by summer $(0.19 \%)$ and winter $(0.14 \%)$ seasons (Table 5). Prathapkumar et al. (1997) reported $10 \%$ mortality and $20 \%$ drop in egg production due to aflatoxin B1 in the diet. Choudary (1986) reported reduction in mortality and gradual increase in egg production when feed suspected for aflatoxicosis was changed.
\end{abstract}

\section{Parasitic diseases \\ Ascaridiasis}

Mortality due to Ascaridia galli infection was recorded in $0.22 \%$ in chickens (Table 4). This helminth parasite was recorded in growing $(0.08 \%)$, pullet $(0.03 \%)$ and adult layer $(0.09 \%)$ birds (Table 4$)$. Rahman and Samad (2003) reported highest case fatality in pullet (43.33\%), followed by adult layers (18.52\%) reared in litter system. Significantly $(\mathrm{p}<0.01)$ highest mortality rate during both in summer and winter $(0.08 \%)$ and lowest during rainy $(0.05 \%)$ season (Table 5), which supports the findings of Rahman and Samad (2003).

\section{Tapeworm infestation}

The occurrence of Raillietina spp. in chickens has been reported from Bangladesh (Samad et al., 1985; 1986). This study recorded only $12(0.32 \%)$ chickens affected with tapeworms, of which $6(0.16 \%)$ birds died (Table 4). Higher prevalence rate of cestodes have been reported in chickens in backyard flocks in Bangladesh (Samad, 2000). Highest mortality of tapeworm infestation was recorded during rainy $(0.08 \%)$, followed by winter $(0.05 \%)$ and summer $(0.03 \%)$ seasons (Table 5).

\section{Coccidiosis}

Coccidiosis, caused by Eimeria spp. is the only recorded protozoan disease in chickens, which is characterized by blood tinged feces, ruffled feathers, loss of appetite, poor growth and reduced egg production (Karim and Trees, 1990; Mosleuddin et al., 1993; Samad and Chakraborty, 1993b). This study recorded an overall 1.32\% (n = 49) mortality rate in large type chickens supports the report of Sil et al. (2002) who reported $2.29 \%$ mortality among 8 to 20 weeks old cockerels. However, higher case fatality rates due to outbreaks of coccidiosis have been reported from Bangladesh by Bhattacharjee et al. (1996) and Talha et al. (2001) who reported 9.40 and $5.51 \%$ case fatality rate in chickens due to coccidiosis. The reason for decreasing the morbidity and mortality rates caused by coccidiosis could be due to improve hygienic management in cage system and routine use of coccidiostats in their flocks.

Coccidiosis was recorded from growing (>3 weeks age) birds up to laying stage (Table 4), and during all the seasons of the year (Table 5) but significantly $(\mathrm{p}<0.01)$ higher mortality was recorded during winter $(0.62 \%)$ months in comparison to summer $(0.43 \%)$ and rainy $(0.27 \%)$ seasons (Table 5$)$.

\section{Nutritional deficiency}

It is necessary to supply balanced feed to layer chickens to express their genetic potential and for peak production. Due to deficiency of nutrients uneven growth, rough feather development, decreased egg production and lowered hatchability may occur, however some characteristic signs and lesions are developed in severe deficiency of specific nutrients. An overall 47 (1.27\%) chickens showed the deficiency signs during he study period of which $25(0.68 \%)$ layer chickens died due to nutritional deficiency.

Nutritional deficiency was recorded in all age groups of chickens (Table 4). Significantly $(\mathrm{p}<0.01)$ highest mortality in chickens due to nutritional deficiency was recorded during rainy $(0.27 \%)$ in comparison to summer $(0.24 \%)$ and winter $(0.16 \%)$ seasons (Table 5). These findings support the report of Rahman and Samad (2003). 


\section{Ascites and Hydropericardium hepatitis syndrome (HHS)}

These disorders caused mortality of $0.49 \%$ in chickens (Table 4 ). These disorders commonly occur in growing layer chickens (Table 4). Clinically affected layer birds with ascites were smaller the normal and depressed with ruffled feathers and showed abdominal distension with respiratory distress and cyanosis. Necropsy lesions included hypertrophy of the right ventricle, presence of straw color fluid in the peritoneal cavities. HHS was first reported by Rahman et al. (2001) in Bangladesh. In HHS, excess accumulation of fluid in the pericardial sac and multifocal hepatic necrosis were present. However, this disease was recorded in all the three seasons but significantly $(\mathrm{p}<0.01)$ highest in summer $(0.24 \%)$, followed by rainy $(0.14 \%)$ and winter $(0.11 \%)$ seasons (Table 5). These results support the findings of Rahman and Samad (2003) who reported 46.15\% HHS in summer in comparison to rainy $(23.08 \%)$ and winter $(30.77 \%)$ months.

\section{Cannibalism}

Cannibalism are recognized as feather pulling, vent and head picking followed by hemorrhages. Cannibalism caused mortality in $0.27 \%$ layer egg type chickens which could be compared well with the earlier report of Rahman and Samad (2003) who reported $0.17 \%$ cases of cannibalism in Bangladesh. In layer it was $0.18 \%$, followed by pullets $(0.08 \%)$ and growing $(0.02 \%)$ birds (Table 4$)$. Highest mortality rate was recorded during summer $(0.11 \%)$ in comparison to winter $(0.08 \%)$ and rainy $(0.08 \%)$ seasons (Table 5). The light intensity, stocking density, vitamin and mineral deficiency, insufficient feeder or drinker space, irritation from external parasites have been reported to be the predisposing factors of cannibalism.

\section{Egg bound disorder}

Egg bound disorder is a condition in which an egg is lodged in the vagina but can not be laid. It may be due to inflammation of the oviduct, partial paralysis of the muscles of the oviduct or production of a large egg that is difficult to lay. Young pullets laying an unusually large egg are more prone to the problem. When impaction occurs in the uterus or vagina, egg enclosed by shell membranes may be found in the abdominal cavity. This indicates that eggs continued to form but were refluxed back into the peritoneal cavity. Mortality due to this disorder was recorded as $0.50 \%$ in layer chickens (Table 4). The egg bound problem in layer chickens has also been reported from Bangladesh by Rahman and Samad (2003) and Bhattacharjee et al. (1996).

\section{Egg peritonitis}

Mortality due to the egg peritonitis was recorded as $0.25 \%$ layer chicken which supports the report of Rahman and Samad (2003) who reported $2.74 \%$ proportionate case fatality rate due to egg peritonitis in layer chickens. This disorder of laying hen was uniformly distributed through all the season of the year (Table 5).

\section{REFERENCES}

1. Al-Sadi HJ, Basher HA and Qubih TS (2000). A retrospective study of clinically diagnosed poultry diseases in Nenevha Province. Iraq. Iraqi Journal of Veterinary Science 13: 107-113.

2. Anjaneyulu Y, Babu NS and James RM (1998). Mortality pattern in broilers in Prakasam district. Indian Journal of Veterinary Pathology 22: 44-46.

3. Asghar A, Farooq M, Mian M, Perveez A and Khurshid A (2000). Economic of broiler production in Mardan Division. Journal of Rural Development and Administration 32: 56-64.

4. Babiker MA, Tawfeig A, Yahia IE and Koura K (2009). Mortality and diseases status in layer chicken flocks reared in traditional farms in Khartoum-Sudan. International Journal of Poultry Science 8: 264-269.

5. Bhattacharjee PS, Kundu RL, Biswas PK, Mazumder JU, Hossain E and Miah AH (1996). A retrospective analysis of chicken diseases diagnosed at the Central Disease Investigation Laboratory, Dhaka. Bangladesh Veterinary Journal 30: 105-113.

6. Biswas HR, Khatun AHM, Miah AH, Hoque MM and Rahman ML (1993). Chicken mycoplasmosis in Bangladesh. Australian Journal of Animal Sciences 6: 249-251.

7. Cheesbrough GR (1985). Medical Laboratory Manual for Tropical Countries. $1^{\text {st }}$ edn., Butterworth Co., Kent. 


\section{Z. Uddin and others}

8. Choudhury KA, Amin MM, Rahman A and Ali MR (1985). Investigation of natural outbreak of fowl cholera. Bangladesh Veterinary Journal 19: 49-56.

9. Choudary C (1986). Outbreak of 'fatty liver syndrome' in commercial layer farms. Poultry Adviser 19:59-60.

10. Chowdhury TIMFR, Sarker AJ, Amin MM and Hossain WIMA (1981). Studies of Newcastle disease in Bangladesh. Bangladesh Veterinary Journal 15: 1-9.

11. Das BC, Dutta GN and Phukan A (2001). Necrotic enteritis among fowls in Assam. Indian Journal of Comparative Microbiology, Immunology and Infectious Diseases 22: 82-83.

12. Dewan ML and Das PM (1989). Necrotic gastro-enteritis in poultry. Bangladesh Veterinarian 6: 54-55.

13. Farooq M, Mian MA, Durrani FR and Syed M (2002). Prevalent diseases and mortality in egg type layers under subtropical environment. Livestock Research for Rural Development 14: 144-151.

14. Ghodasara DJ, Joshi BP, Jani PB, Gangopadhyay BM and Prajapati KS (1992). Pattern of mortality in chickens. Indian Veterinary Journal 69: 888-890.

15. Giasuddin M, Sil BK, Alam J, Koike I, Islam MR and Rahman MM (2002). Prevalence of poultry diseases in Bangladesh. Journal of Biological Sciences 2: 212-213.

16. Hossain MA and Islam MA (2004). Seroprevalence and mortality in chickens caused by Pullorum disease and Fowl typhoid in certain Government Poultry Farms in Bangladesh. Bangladesh Journal of Veterinary Medicine 2: 103-106.

17. Islam MT and Samad MA (2003). Outbreaks of infectious bursal disease in vaccinated and unvaccinated commercial cockerel farms in Bangladesh. Bangladesh Journal of Veterinary Medicine 1: 21-24.

18. Islam MR, Das BC, Hossain K, Lucky NS and Mostafa MG (2003). A study on the occurrence of poultry diseases in Sylhet region of Bangladesh. International Journal of Poultry Science 2: 354-356.

19. Kamal AHM and Hossain MI (1992). Pathological investigation on the mortality of chickens in Bangladesh Agricultural University Poultry Farm. Bangladesh Veterinarian 9: 20-25.

20. Karim MJ and Trees AJ (1990). Isolation of five species of Eimeria from chickens in Bangladesh. Tropical Animal Health and Production 22: 153-154.

21. Kim HJ, Kong MI, Chung UK, Kang MI and Chung UI (1996). Survey of enteric diseases in chickens. Korean Journal of Veterinary Research 36: 1007-1012.

22. Kitsopanidis JP and Manos H (1991). Evaluation of the degree of variation in profitability of poultry meat production according to certain factors. Epitheorese Zootenhnikes Epistemes 14: 59-71.

23. Mahajan NK, Jindal N and Kulshsreshtha RC (1994). Major broiler diseases in some parts of Haryana. Indian Journal of Animal Science 64 1118-1122.

24. Mosleuddin, Dewan ML and Choudhury KA (1972). Avian leukosis in Mymensingh district. Bangladesh Veterinary Journal 6: 39-42.

25. Mosleuddin and Dewan ML (1974). Incidence and diagnosis of Marek's disease in two poultry farms of Bangladesh. Bangladesh Veterinary Journal 8: 45-48.

26. Moslehuddin, Kabir MH, Hossain MI and Rahman MH (1993). An investigation into coccidiosis in chicken. Bangladesh Veterinarian 10: 13-16.

27. North MO and Bell DO (1990). Commercial Chicken Production Manual. $4^{\text {th }}$ edn., Chapman and Hall, International Thomson Publishing, New York, USA.

28. Parimal R and Balasubramanian GA (1992). Outbreak of Newcastle disease in an organized farm. Indian Veterinary Journal 69: 556-557.

29. Parker MT and Collier LH (1990). Principles of Bacteriology Virology and Immunity. Vol. 2 and 3, $8^{\text {th }}$ edn. British Library Cataloguing in Publication data, London WCIE. 7DP. 
30. Petek M (1999). Production traits and economic efficiencies of different genotypes of layers reared by enterprises in Bursa province and its near vicinity. Veteriner Fakultesi Dergisi Uludag Universitesi 18: 6577.

31. Philip RG and Moitra RN (1993). An outbreak of infectious bursal disease in poultry in Bhutan. Bhutan Journal of Animal Husbandry 14: 29-32.

32. Prabhakaran V, Chithravel V, Kokilaprabhakaran S and Saravanan CS (1997). Infectious bursal disease with concurrent infection of Escherichia coli and coccidiosis: haemogram and serum chemistry. Indian Journal of Animal Health 36: 7-9.

33. Prathapkumar SH, Rao VS, Paramkishan RJ and Bhat RV (1997). Disease outbreak in laying hens arising from the consumption of fumonisin contaminated food. British Poultry Science 38: 475-479.

34. Qu FQ, Yong SQ, Jiu B, Zhang DZ, Li HW and Chen SY (1997). Diagnosis and control of swollen head syndrome in layers. Chinese Journal of Veterinary Medicine 23: 23.

35. Rahman MA and Samad MA (2003). Pattern of occurrence of single and concurrent diseases associated with mortality in commercial chickens in Bangladesh. Bangladesh Journal of Veterinary Medicine 1: 15-20.

36. Rahman MA and Samad MA (2004). Important systemic and miscellaneous diseases associated with morbidity and mortality in commercial poultry in Bangladesh. Bangladesh Journal of Veterinary Medicine 2: 91-98.

37. Rahman MA and Samad MA (2005). Important viral diseases associated with mortality of layer chickens in commercial poultry farms in Bangladesh. Bangladesh Journal of Veterinary Medicine 3: 1-5.

38. Rahman MM, Chowdhury EH, Hossain MM, Bari ASM and Das PM (2001). Pathological studies on hydropericardium-Hepatitis syndrome in broiler birds in Bangladesh. Bangladesh Veterinary Journal 35: 2528.

39. Rahman MA, Samad MA, Rahman MB and Kabir SMA (2004). Bacterio-pathological studies on salmonellosis, colibacillosis and pasteurellosis in natural and experimental infections in chickens. Bangladesh Journal of Veterinary Medicine 2: 1-8.

40. Rao DG, Rao PR and Rao MVS (1990). A note on Infectious bursal disease outbreak in a poultry flock in Andhra Pradesh. Indian Veterinary Journal 67: 567-568.

41. Sah RL, Kataria JM, Arya SC and Verma KC (1995). Outbreaks of acute Infectious bursal disease causing high mortality in chicken. Indian Journal of Comparative Microbiology, Immunology and Infectious Diseases 16: 7-13.

42. Saleque MA, Rahman MH and Hossain MI (2003). A retrospective analysis of chicken diseases diagnosed at the BRAC Poultry Disease Diagnostic Centre of Gazipur. Bangladesh Journal of Veterinary Medicine 1: 2931.

43. Samad MA (2000). Overview of livestock research reports published during the twentieth century in Bangladesh. Bangladesh Veterinary Journal 34: 53-149.

44. Samad MA (2005). Poultry Science and Medicine. $1^{\text {st }}$ Pub., LEP No. 10, BAU Campus, Mymensingh, Bangladesh.

45. Samad MA, Alam MM and Rahman A (1985). Incidence of gastro-intestinal parasitic infection in domestic fowl of Bangladesh. Poultry Adviser 18: 35-38.

46. Samad MA, Alam MM and Bari ASM (1986). Effect of Raillietina echinobothrida infection on blood values and intestinal tissues of domestic fowls of Bangladesh. Veterinary Parasitology 21: 279-284.

47. Samad MA and Chakraborty SR (1993). Outbreaks of acute aspergillosis in broiler birds in Bangladesh. Poultry Adviser 26: 63-65. 


\section{Z. Uddin and others}

48. Samad MA and Chakraborty SR (1993). Chemothrapeutic management of acute outbreaks of caecal coccidiosis in broiler birds in Bangladesh. Journal of Protozoological Research 3: 140-143.

49. Sarker AJ (1976). The prevalence of avian diseases in Bangladesh Agricultural University Poultry Farm, Mymensingh. Bangladesh Veterinary Journal 10: 61-66.

50. Shil GC, Ehsan MA, Rahman MS, Anower AKMM and Islam MR (2003). Diseases associated with mortality and pathological changes in cockerel birds. Bangladesh Journal of Veterinary Medicine 1: 33-38.

51. Siddique M, Sabri MA and Khan MZ (1986). Outbreak of Newcastle disease in vaccinated chicken flocks in and around Faisalabad. Pakistan Veterinary Journal 6: 41- 45.

52. Sil GC, Das PM, Islam MR and Rahman MM (2002). Management and disease problem of cockerels in some farms of Mymensingh, Bangladesh. International Journal of Poultry Science 1: 102-105.

53. Singh KC, Dhawedkar PRG and Jaiswal RK (1994). Comparative studies on bursa and body weight ratios of chicks, post infection with a field and vaccine strains of IBDV. Indian Journal of Veterinary Research 3: 59.

54. Steel RGD and Torrie JH (1981). Principles and Procedures of Statistics: A biometrical approach. $2^{\text {nd }}$ edn., McGraw-Hill, Singapore.

55. Talha AF, Hossain SMMM, Chowdhury EH, Bari ASM, Islam N and Das PM (2001). Poultry diseases occurring in Mymensingh district of Bangladesh. Bangladesh Veterinarian 18: 20-23.

56. Tolimir N and Masic B (2000). The results of European egg production tests in 1997-1998. Zivinarstvo 35: 66-68.

57. Zaheer-ud-Din, Frooq M, Durrani R, Chand N and Ahmed J (2001). Status o broilers produced in Swat, Pakistan. Livestock Research or Rural Development 13 : http://www.cipav.org.co/lrrd/Irrd13/3/zahi133.htm

58. Zanella A, Alborali GL, Bardotti, M, Candotti P, Guadagnini PF, Martino PA and Stonfer M (2000). Severe Escherichia coli 0111 septicemia and polyserositis in hens at the start of lay. Avian Pathology 29: 311-317. 